\title{
Drivers of past and predicted changes of rainfall in and around Mainland Southeast Asia
}

\author{
Nikolaos Skliris ( $\square$ N.Skliris@noc.soton.ac.uk) \\ University of Southampton https://orcid.org/0000-0002-2473-2586 \\ Robert Marsh \\ University of Southampton \\ Ivan D. Haigh \\ University of Southampton \\ Melissa Wood \\ University of Southampton \\ Joel Hirschi \\ Southampton Oceanography Centre: National Oceanography Centre
}

\section{Stephen Darby}

University of Southampton

\section{Nguyen Phu Quynh}

Southern Institute of Water Resource Research

\section{Nguyen Nghia Hung}

Southern Institute of Water Resource Research Institute: Oklahoma Water Resources Center

\section{Original Article}

Keywords: Mainland South East Asia, Rainfall, Monsoon, Evaporation, Water Cycle, CMIP5

Posted Date: February 9th, 2021

DOI: https://doi.org/10.21203/rs.3.rs-194416/v1

License: (c) (i) This work is licensed under a Creative Commons Attribution 4.0 International License. Read Full License 


\section{Abstract}

Observational rain gauge/satellite and reanalysis datasets since the 1950s are evaluated for trends in mean and extreme rainfall over Mainland Southeast Asia (MSEA). Rain gauge data indicate strong increases exceeding $50 \%$ in both annual mean precipitation and various extreme precipitation indices over Vietnam and the northwestern part of the peninsula since 1979. A high degree of uncertainty is evident between reanalysis products in capturing long-term trends in continental precipitation. Evaporation increases over adjacent seas - the Arabian Sea, the Bay of Bengal, and the South China Sea in particular- may partially explain increasing precipitation in large parts of MSEA over the last 40 years. The remote influence of ENSO may also partially explain the recent precipitation trend towards a more intense regional hydrological cycle, in response to predominant La Niña states over recent decades. Increasing precipitation in MSEA is also associated with increased monsoon intensity in southeast Asia and a northward shift of the monsoon activity centre towards MSEA over 1979-2018.

Long-term amplification of the regional hydrological cycle is further investigated, through analysis of CMIP5 coupled climate models in historical and RCP4.5/8.5 21st century scenario simulations. The CMIP5 ensemble mean shows robust wide-spread trends in wet season precipitation over the MSEA in both RCP scenarios linked with strong increases in evaporation in all major oceanic moisture sources. Results clearly demonstrate an intensification of the regional water cycle with increasing frequency and intensity of extreme precipitation events.

\section{Introduction}

Coastal regions of MSEA are densely populated and highly exposed to flooding from coastal, fluvial and surface runoff sources. In Vietnam, 70\% of the population lives in coastal regions, and around major deltas in particular. The Mekong delta, home of $19 \%$ of the population (18.6 million people) and the largest agricultural producing centre in the country (Dun, 2011), has been identified by the IPCC as being one of the three most vulnerable deltas in the world (Nicholls et al. 2007). Densely populated communities in the Mekong delta, most of which lie within $2 \mathrm{~m}$ of current mean sea level, are especially vulnerable to flooding, as a result of their exposure to storms and the annual monsoonal flood pulse. Here we focus on rainfall variability as a driver of flooding in MSEA.

Annual total rainfall in MSEA is dominated by the monsoon season, with occasional but major typhoon contributions on a synoptic timescale. The rainfall pattern is very complex and shows strong spatial and seasonal variability. The wind pattern is characterised by a well-established seasonal regime with winds and associated moisture transport mainly originating from the South China Sea and the western tropical Pacific during winter, and from the northern and western parts of the tropical Indian Ocean during summer (Sun and Wang 2015). Oceanic sources of moisture are known to provide the dominant contribution to precipitation over MSEA compared with continental moisture sources (Wu et al. 2012). There are also strong orographic constraints which interact with the monsoon and the large-scale atmospheric circulation to shape local continental precipitation (Wang and Chang 2012), leading to pronounced spatial variations over MSEA (Fig. 1). In particular large-scale mountain ranges in the western part of the peninsula between Myanmar and Thailand present an orographic meridional barrier that partitions rainfall east and west of the barrier (Tsai et al. 2015). Mountain ranges along much of Vietnam likewise present a meridional barrier that partly blocks westward moisture fluxes from penetrating further inland during winter and tropical storms that originate in the western Pacific during summer. The wet season across most of MSEA typically starts at mid-spring with the onset of the Southeastern Asian summer monsoon and peaks in summer but as a consequence of combined orographic and seasonal wind patterns the wet season starts later and peaks in Autumn along the eastern part of the peninsula in Vietnam (Fig. 2). In the latter region, relatively strong precipitation persists even during winter, whereas in the rest of the peninsula precipitation levels are very low (Fig. 2d). At the northern border of MSEA, the Tibetan Plateau blocks winter cold events from the north, thereby generally confining the winter monsoon to southeastern Asia (Yanai and Wu 2006).

Page $2 / 28$ 
The frequency and intensity of flooding events across the region are expected to increase as the hydrological cycle amplifies with anthropogenic global warming (Held and Soden, 2006). Observations and climate model simulations show that precipitation extremes intensify in a warming climate (e.g. O'Gorman 2015). The Clausius-Clapeyron relationship predicts an increase in the water holding capacity of air of approximately $7 \%$ per degree Celsius rise in temperature. Following energy and moisture balance constraints, the increased atmospheric moisture and its horizontal transport in the lower troposphere are expected to increase global mean precipitation and strengthen the mean evaporation minus precipitation pattern, with wet regions becoming wetter and dry regions becoming drier (Held and Soden, 2006). Satellitederived observations over the global tropical ocean clearly show a robust tendency for a water cycle amplification under anthropogenic warming (Liu and Allan, 2012; Liu et al. 2012; Chou et al. 2013). Liu and Allan (2012), using multiple satellite-based observational products to analyse the response of the global tropical ocean precipitation intensity distribution to changes in surface temperature, found that the wetter area precipitation shows a robust response to temperature rise of around $20 \% / \mathrm{deg}$. K. A pronounced increase of tropical ocean rainfall over the last few decades is evidenced in several studies (Liu et al. 2012; Fasullo 2012; Skliris et al. 2014). As surface temperature rises, the largest increases in mean and extreme precipitation are expected in tropical regions of moisture convergence. Monsoon rainfall and extreme tropical storms in Southeast Asia are therefore at high risk of intensification, with potentially severe socioeconomic implications for these regions.

Due to the highly sporadic and localised character of rainfall, and the large difficulties in obtaining reliable in-situ measurements of evaporation and precipitation, over the ocean in particular, there is a very high level of uncertainty in the estimation of observed variability and trends in surface freshwater fluxes (Hegerl et al. 2015). It is particularly difficult to assess drivers of long-term changes in regional continental-scale water cycling. This is especially the case in dynamically complex and data-sparse areas like the MSEA where local precipitation is strongly shaped by interactions between orography and large-scale, seasonally reversing, atmospheric circulation related to the monsoon, and which is also influenced by sporadic but strong storm events (typhoons) mainly originating in the Western Tropical Pacific. The interannual/decadal rainfall pattern is also strongly modulated by natural climate variability, with MSEA being located at the crossroads of the major coupled ocean/atmosphere variability modes of the tropical Pacific (El Nino Southern Oscillation) and Indian (Indian Ocean Dipole) Oceans. Insights into changes in water cycling through time, and especially changes in moisture transport from ocean/land sources and moisture convergence over the MSEA, can be provided by Numerical Weather Prediction (NWP) model re-analyses and historical climate model simulations. However, atmospheric reanalyses have often been found to be unreliable for assessing long-term trends in the hydrological cycle over both land and ocean, violating basic physical constraints and being inconsistent with observational estimates (Trenberth et al. 2011; Skliris et al. 2014). There are also large discrepancies in the evolution of the global monsoon rainfall over land as estimated from various reanalyses, including contradictory and likely to be spurious trends both prior to and during the satellite era, as well as inconsistencies with moisture convergence estimated from the mass-corrected atmospheric moisture budget (Fasullo 2012). Climate model historical simulations also show very large variations concerning changes in the hydrological cycle whilst they appear to underestimate surface freshwater flux and salinity responses to warming compared with observations (Durack et al. 2012; Zika et al. 2018; Skliris et al. 2020). Satellite-derived products have been shown to be more reliable tools to diagnose trends in precipitation (Fasullo 2012; Liu and Allan 2012). Although they also present uncertainties mainly arising from discontinuities in satellite data composition, with the inclusion of SSM/I data in 1987 presenting the major transition event (e.g. Schanze et al. 2010), there is a better consistency amongst satellite-derived precipitation products as compared to re-analyses (Liu and Allan 2012). Satellitederived precipitation products, together with observationally constrained objectively analysed evaporation fields, seem to better diagnose hydrological cycle changes over the ocean compared with re-analyses (Schanze et al. 2010; Skliris et al. 2014; Skliris et al. 2020). Satellite-derived products are also shown to better diagnose trends in monsoon rainfall over land in a warming climate compared to re-analyses and climate models (Fasullo 2012). CMIP5 simulations indicate a precipitation response to warming and precipitation trend in the wetter areas of tropical regions of $\sim 5 \% / \mathrm{deg}$. $\mathrm{K}$ and 
$0.6 \% /$ decade, respectively, over the recent historical period (Liu et al. 2012). However, these values were much lower compared to GPCP satellite-derived observations over the same regions at $\sim 13-15 \% / \mathrm{K}$ and $2.4 \% /$ decade, respectively, suggesting that climate models largely underestimate the observed precipitation responses (Liu et al. 2012). One of the first climate model analyses for monsoon rainfall regions, based on the CMIP3 ensemble projections, showed a large increase in precipitation that was spatially coherent throughout MSEA and consistent amongst most climate models (Fasullo 2012). CMIP5 model projections also show a robust increase in Southeast Asia summer monsoon rainfall over the $21^{\text {st }}$ century, however there is a large inter-model spread for both intensity and the spatial pattern of change (Zhou et al 2019). More recently, CMIP6 model simulations also reveal an accentuation of contrasts between wet and dry regions in the tropics/sub-tropics but with rainfall in wet regions increasing substantially more than decreasing in dry regions (Schurer et al. 2020). CMIP6 model projections also reproduce this strong enhancement of global land monsoon rainfall pattern with the largest rainfall increases being obtained in the Southeast Asian monsoon regions (Chen et al. 2020). However, the uncertainty of precipitation projections is still very high, for the long-term projections and the strongest emissions scenario in particular, with the large inter-model spread mainly being attributed to the model-dependent response to sea surface warming (Chen et al. 2020). Ge et al. (2019) investigated projected changes in precipitation extremes in Southeast Asia based on six high-resolution regional climate models and using the scenarios of $1.5^{\circ} \mathrm{C}$ and 2 ${ }^{\circ} \mathrm{C}$ global warming levels exceeding pre-industrial conditions. Their results showed that projected changes in various precipitation extreme indices were significantly amplified over the MSEA in both scenarios, while precipitation extremes were highly sensitive to the additional $0.5^{\circ} \mathrm{C}$ increase in global warming.

Our overall aim in this paper is to investigate large-scale coupled atmosphere/ocean processes that drive mean and extreme rainfall in the MSEA both in the past (1950 to present) and future (present to 2100). We do this using observationally-based (rain gauge and/or satellite-derived) and atmospheric model re-analysis data and using climate model projections. Our first objective is to assess historical long-term trends in mean and extreme precipitation over MSEA. Our second objective is to investigate links between changes in evaporation in oceanic moisture source regions and MSEA precipitation. Our third objective is to assess the impact of monsoon activity and large-scale natural climate variability modes of the tropical Indian and Western Pacific oceans on precipitation variations in and around MSEA. Our fourth objective is to examine future climatic trends in mean and extreme precipitation over MSEA and their link to ocean evaporation trends from CMIP5 coupled climate model $21^{\text {st }}$ century projections.

\section{Data And Models}

Three observationally-based (satellite-derived and/or gauge data) and two atmospheric re-analysis gridded precipitation datasets are used here to investigate precipitation variability and long-term trends over and around MSEA. The three observationally-based datasets comprise:

(1) The Global Precipitation Climatology Project (GPCP v2.3; https://psl.noaa.gov/data/gridded/data.gpcp.html), monthly mean data over land and ocean on a $2.5^{\circ} \times 2.5^{\circ}$ grid, available from 1979 , based on rain gauge observations over land and satellite retrievals (Adler et al. 2003);

(2) The Asian Precipitation - Highly-Resolved Observational Data Integration Towards Evaluation (APHRODITE), daily data spanning $1950-2007$ on a $0.25^{\circ} \times 0.25^{\circ}$ grid (Yatagai et al 2012; APHRO_MA-V1101, aphrodite.st.hirosaki-u.ac.jp);

(3) Climate Prediction Centre (CPC), Global Unified Gauge-Based Analysis of Daily Precipitation (https://psl.noaa.gov/data/gridded/data.cpc.globalprecip.html), daily data spanning $1979-2018$ on a $0.5^{\circ} \times 0.5^{\circ}$ grid.

The two atmospheric reanalysis-based evaporation and precipitation datasets used here are obtained from: 
(1) NCEP/NCAR Reanalysis 1 (https://psl.noaa.gov/data/gridded/data.ncep.reanalysis.html) spanning 1948-present on a $2.5^{\circ} \times 2.5^{\circ}$ grid (Kistler et al. 2001) and

(2) The European Centre for Medium-Range Weather Forecasts ERA5 global reanalysis

(https://www.ecmwf.int/en/forecasts/datasets/reanalysis-datasets/era5) spanning 1979-present on a $0.25^{\circ} \times 0.25^{\circ} \mathrm{grid}$ (Hersbach et al. 2020).

Note that evaporation is also obtained by the Objectively Analyzed air-sea Fluxes (OAFlux) dataset developed by Yu et al. (2008) (http://rda.ucar.edu/datasets/ds260.1/), that blends NCEP and ERA-40 reanalysis products with satellite surface meteorology through an objective synthesis, with monthly data spanning 1958 -present on a $1^{\circ} \times 1^{\circ}$ grid. Nearsurface salinity trends are assessed using the UK Met Office Hadley Centre Enhanced Ocean Data Assimilation and Climate prediction (ENACT) archive version4 (En4, subversion En4.1.1, $1^{\circ} \times 1^{\circ}$ grid) dataset (http://www.metoffice.gov.uk/hadobs/en4) developed by Good et al. (2013).

We have chosen 6 sub-regions to investigate changes in precipitation over the MSEA, each of which is characterised by different precipitation/wind seasonal patterns and orographic constraints, namely: (1) South Vietnam, (2) North Vietnam, (3) Central MSEA, (4) North MSEA, (5) South Myanmar, and (6) North Myanmar (see Fig. 1). For simplicity rectilinear boxes are used to define the 6 sub-regions. Note that the geographical areas of sub-regions named by a specific country largely consist of that country (or the largest part of that country) but may also include smaller portions from other nations.

Following the atmospheric backtracking analysis of continental precipitation by Van der Ent et al. (2013) we have identified three major oceanic regions supplying moisture for MSEA precipitation, namely: The South China Sea, the Bay of Bengal, and the Arabian Sea. A significant oceanic moisture source is defined when on average more than $20 \%$ of the total evaporation, and at least $250 \mathrm{~mm}_{\text {year }}^{-1}$ of evaporation from the source region, ends up as continental precipitation (Van der Ent et al. 2013). Area-averaged monthly evaporation timeseries are constructed for each oceanic region.

In order to investigate future changes in mean precipitation and precipitation extremes over MSEA we analysed the output of the historical, and Representative Concentration Pathways 4.5 (RCP4.5) and 8.5 (RCP8.5) simulations from 33 Coupled Model Intercomparison Project Phase 5 (CMIP5) models (Taylor et al. 2012), including ACCESS1-0, ACCESS1-3, bcc-csm1-1, BNU-ESM, CanESM2, CCSM4, CESM1-BGC, CESM1-CAM5, CMCC-CM, CNRM-CM5, CSIRO-Mk3-6-0, ECEARTH, FGOALS-g2 FIO-ESM, GFDL-CM3, GFDL-ESM2G, GFDL-ESM2M, GISS-E2-H, GISS-E2-R, HadGEM2-CC, HadGEM2ES, inmcm4, IPSL-CM5A-LR, IPSL-CM5A-MR,

IPSL-CM5B-LR, MIROC5, MIROC-ESM, MIROC-ESM-CHEM, MPI-ESM-LR, MPI-ESM-MR, MRI-CGCM3,NorESM1-M, and NorESM1-ME. The periods analysed include 1861-2005 for the historical simulations, and 2006-2100 for the RCP4.5 and RCP8.5 simulations. We constructed ensemble mean monthly timeseries of evaporation (for the three oceanic moisture source regions) and precipitation (for MSEA and the six MSEA sub-regions). We use extreme precipitation indices based on daily precipitation data for both observations (CPC) and CMIP5 outputs as defined by the Expert Team on Climate Change Detection and Indices (ETCCDI) to quantify climate extremes with reoccurrence times of a year or shorter (Sillmann et al. 2013a). Extreme precipitation indices employed here include RCPTOT (total precipitation of wet days), SDII (simple daily precipitation intensity), R10mm (number of days of heavy rainfall, defined as $>10 \mathrm{~mm} /$ day), R20 mm (number of days of very heavy rainfall, defined as $>20 \mathrm{~mm} /$ day), and CDD (number of consecutive dry days). Wet days are defined as days with $>1 \mathrm{~mm}$ of rainfall. The annual extremes of the daily CMIP5 data have been obtained from the ETCCDI extremes indices archive at the Canadian Centre for Climate Modelling and Analysis (https://climatemodelling.canada.ca/data/climdex/climdex.shtml). 
We construct monthly anomaly time series for all datasets by subtracting the climatological monthly mean from the monthly data at each grid point. Seasonal and annual anomalies are then constructed from the monthly anomalies, allowing us to compute linear trends for both the observational and CMIP5 historical (1860-2005), and the RCP4.5/8.5 (2006-2100) time-series. Uncertainties in linear trends are estimated using the standard error of a linear fit (least squares).

\section{Results And Discussion}

\subsection{Long-term historic trends in mean and extreme precipitation over MSEA}

Land precipitation based on the rain-gauge-based APHRODITE dataset, analysed here to assess long-term trends, show an overall increase in precipitation since the 1950s but there is no coherent spatial signal over MSEA. There is a statistically significant (at the $95 \%$ confidence interval) increase in annual precipitation ( 30-40\% in respect to climatological annual mean over 1950-2007) throughout Vietnam (sub-regions 1 and 2) and decreasing trends in North Myanmar (sub-region 6) throughout the wet season, with maximum changes during summer (Fig. 3). On the other hand, there are very low trends (not statistically significant) in large parts of north and central parts of MSEA including in South Myanmar and Thailand, in agreement with the study of Tsai et al. (2015).

Analysis of precipitation data from the NCEP/NCAR reanalysis over 1950-2018 shows a statistically significant positive trend only over southern MSEA ( 20-30\% increase with respect to the climatological annual mean) with a more widespread signal compared to the rain gauge dataset and low (not statistically significant) trends roughly north of $15^{\circ}$ North (Fig. 4). In general, there are large spatial discrepancies between the two datasets in representing long-term trends, over the northwest MSEA in particular. Moreover, the trend in land precipitation in NCEP/NCAR re-analysis is much less than that over the ocean around MSEA. Both NCEP/NCAR and $20^{\text {th }}$ Century reanalysis products suggest a strong large-scale increase in precipitation in the eastern tropical Indian Ocean and western tropical Pacific Ocean over that period (Skliris et al. 2014). This large-scale, spatially-coherent, pattern of increasing oceanic precipitation since the 1950s appears to be the most pronounced signal of change within the global ocean.

Spatial patterns in precipitation trends over 1979-2018 as derived by the CPC rain gauge-based dataset show spatially variable changes, with larger precipitation increases exceeding $50 \%$ (with respect to the climatological mean) over Vietnam (Sub-regions 1 and 2) and the northwestern part of the peninsula (sub-region 6)), versus much lower trends, or even precipitation decreases, over large parts of central and northern MSEA. Seasonal precipitation trend patterns (Fig. 5 and Table 1) indicate that this contrast is evidenced throughout the summer monsoon season (Fig. 5a), but it is also present in the declining phase of the monsoon in autumn (Fig. 5c). A pronounced widespread increasing precipitation trend persists along the Vietnam coast in winter (Fig. 5d).

Importantly, the daily CPC data clearly demonstrate an intensification of extreme precipitation events over 1979-2018 with highly statistically significant positive trends in several extreme precipitation indices considered here throughout Vietnam (sub-regions 1 and 2) and the northwestern part of the peninsula, in North Myanmar (sub-region 6) in particular (Fig. 6 and Table 2). Increases in total wet season precipitation (PRCPTOT) and in number of days of heavy (R10mm) and extreme (R20mm) rainfall exceed $50 \%$ in the above areas over 1979-2018. There is also a significant decrease in the dry season period throughout Vietnam (Fig. 6d). On the other hand, together with mean summer precipitation, extreme precipitation indices are significantly reduced over parts of Cambodia, Thailand, and Laos over 1979-2018.

Analysis of satellite-derived ocean precipitation (Fig. 7a) and near surface salinity (Fig. 7d) show that ocean precipitation has increased and salinity decreased, respectively, around MSEA over the last 40 years (1979-2018) indicating an accelerated broad-scale freshening of the tropical eastern Indian and western Pacific oceans over that period (Skliris et al. 2014). Spatial patterns of precipitation trends since 1979 in southeast Asia show a relatively good consistency between reanalyses (NCEP/NCAR, ERA5) and satellite-derived precipitation (GPCP) over the ocean, but much larger discrepancies

Page 6/28 
over land. Low-resolution GPCP show a statistically significant positive trend over southern MSEA but is largely inconsistent with the CPC rain-gauge dataset (Fig. 7c) in terms of the identification of precipitation trends over large parts of the peninsula, in northwestern MSEA in particular. The more recent higher resolution ERA5 reanalysis (Fig. 7b) shows that precipitation trends over MSEA are consistent in sign over the largest part of the peninsula, but much lower in magnitude compared with the CPC rain-gauge data over 1979-2018.

Rain-gauge data (Aphrodite and CPC) indicate a strong widespread precipitation increase throughout Vietnam since the 1950's which has accelerated over the last 40 years. This pronounced change in precipitation obtained here is in contrast with the study of Nguyen et al. (2014), who investigated variations of Vietnam rainfall based on 60 meteorological stations over the earlier period of 1971 to 2010 but found no statistically significant trends over most of the Vietnam region. However, in a more recent study Gao et al. (2019) found a strong significant increase in spring precipitation with a concomitant decrease in extreme drought throughout Vietnam during the past 4 decades, in agreement with our results.

\subsection{Links between ocean evaporation and precipitation trends over MSEA}

Here we investigate links between land precipitation and evaporation changes in the main oceanic sources of moisture for MSEA as defined in Van der Ent et al. (2013): (1) the South China Sea, (2) the Bay of Bengal, and, (3) the Arabian Sea. Seasonal surface wind patterns clearly reveal a reversing source of moisture fluxes to MSEA from the South China Sea in winter, to the Bay of Bengal in summer (Zhang et al. 2019). The Bay of Bengal moisture contribution for MSEA precipitation peaks in June-August with the summer monsoon peak mainly supplying moisture in the northwestern part of the peninsula where on average it contributes locally to 10-25\% of total precipitation (Van der Ent et al. 2013). The South China Sea moisture contribution peaks in August-November mainly supplying moisture to the east coast along Vietnam, when the monsoon period is in the declining phase, contributing to 10-25\% of total precipitation (Van der Ent et al. 2013). The Arabian Sea, although relatively distant, is also a significant moisture source, mainly supplying moisture to northwestern MSEA where on average it contributes to $10-20 \%$ of total precipitation.

Figure 8 shows the spatial pattern of long-term trends in evaporation since the 1950s from NCEP/NCAR (1950-2018) and OAFlux (1958-2018). Both products indicate broad-scale evaporation increases in oceanic moisture sources in the northwestern Indian Ocean (including the Bay of Bengal and the Arabian Sea) and the South China Sea supplying moisture to MSEA. Our analysis of area-averaged ocean evaporation based on the OAFlux dataset (Fig. 9) shows highly statistically significant positive trends over the Arabian Sea $(0.085 \mathrm{~mm} /$ day/decade), Bay of Bengal (0.069 $\mathrm{mm} /$ day/decade), and South China Sea $(0.096 \mathrm{~mm} /$ day/decade), amounting to increases of annual evaporation of $13 \%$, $10 \%$, and $16 \%$, respectively, during 1958-2018. The long-term evaporation increases obtained here in the oceanic moisture sources for MSEA precipitation are in-line with increasing surface warming (not shown) that would act to enhance ocean latent heat fluxes in these regions. This trend seems to be part of a broad-scale spatially coherent pattern of evaporation increase in the tropical Indian and western Pacific Oceans that is consistent with a warming-driven intensification of the global hydrological cycle, clearly evidenced over the last 50-60 years (Durack et al. 2012; Skliris et al. 2016; Zika et al. 2018).

OAFlux evaporation analysis also shows that evaporation trends become stronger over 1979-2018 in the main three moisture source regions (Arabian Sea: $0.123 \mathrm{~mm} /$ day/decade; Bay of Bengal: $0.088 \mathrm{~mm} /$ day/decade; South China Sea: $0.0126 \mathrm{~mm} /$ day/decade) as ocean surface warming is accelerating. Area-averaged evaporation and SST anomalies are significantly correlated in all three regions $(R \sim 0.6-0.7, p<0.05)$, as is consistent with the study of Su and Feng (2015) who found a significant positive broad-scale warming-driven linear trend in evaporation in the Tropical Indian Ocean over 1979-2011 based on the analysis of various atmospheric re-analysis products.

Accelerating precipitation trends over large parts of MSEA after 1979 coincide with increasing trends in evaporation in all three of the major oceanic moisture sources. Changes in oceanic moisture source regions supplying moisture in different 
parts of MSEA, together with local changes in moisture transport and convergence, may be responsible for the observed spatial variations in the precipitation changes over the peninsula. The higher rate of evaporation increase between ocean moisture source regions is obtained in the South China Sea, which may partially explain the large increasing precipitation trend over the eastern coast of the peninsula along the whole Vietnam region. This is especially evidenced during autumn and winter when moisture fluxes to Vietnam originate mainly from the South China Sea. On the other hand, moisture transport from the Bay of Bengal and Arabian Sea mainly affect the northwest part of MSEA. Therefore, evaporation increases in these two oceanic moisture source regions may explain at least part of the pronounced precipitation increases over NW MSEA and North Myanmar. As expected, correlations between seasonal area-averaged evaporation in the ocean moisture source regions (OAFlux) and precipitation (CPC) over MSEA sub-regions are generally low and not statistically significant. This is because the climatological mean contribution of each of the three ocean source regions to total precipitation of each sub-region is relatively small (varying between roughly 5 and 30\%, Van der Ent et al. 2013). Statistically significant correlations $(R \sim 0.3)$ were only found in this study between precipitation in Vietnam regions and South China Sea evaporation during the autumn and winter.

Given the large evaporation increases in all three major oceanic moisture sources around MSEA one should expect a widespread precipitation increase throughout the MSEA. However, large parts of central and north MSEA show small and not statistically significant trends in precipitation, whereas there are even statistically significant negative trends in summer and autumn over most of Cambodia and parts of southern Thailand and Laos (see Fig. 5). Orographic constraints, i.e. meridional mountain ranges along Vietnam and western Thailand blocking eastward and westward moisture transport, respectively, together with changes in local moisture convergence, could explain why these increased ocean moisture signals may not reach the interior of the peninsula to enhance precipitation in Central MSEA. Moreover, although oceanic sources of moisture contribute more than continental sources, it is very difficult to assess the contribution of land moisture changes to the local precipitation trend.

\subsection{Impacts of Monsoon and natural modes of climatic variability on precipitation changes over MSEA}

The Monsoon is the major climatic driver controlling precipitation over MSEA, especially during the summer period. The South Asian Summer Monsoon is mainly induced by the land-sea thermal contrast which drives large ocean moisture transport to MSEA (Wu et al. 2012). However, typical indices used to investigate monsoon activity in Southeast Asia, such as the Western North Pacific-East Asian monsoon Index (WNPEA) and the Indian Monsoon Index (IMI), show low correlations to MSEA precipitation (Tsai et al. 2015). Here we use the Summer Asian Monsoon Outgoing Longwave Radiation (OLR) index (SAMOI-A; http://ds.data.jma.go.jp/tcc/tcc/products/clisys/emi.html) to investigate changes in the Monsoon intensity over the study area. SAMOI-A consists of reversed-sign area-averaged OLR anomalies for the area from the Bay of Bengal to the east of the Philippines (averaged over May-October and normalized by the standard deviation). OLR is often used as a proxy for convection in tropical regions with lower values of OLR indicating more enhanced convective activity under cloudy conditions. Positive and negative SAMOI-A values indicate enhanced and suppressed summer monsoon activity, respectively. The spatial pattern of SAMOI-A is roughly centred over the MSEA and Indonesian Seas, enabling us to better capture changes in monsoon activity in this region over summer and early autumn. The correlation pattern between SAMOI-A and summer precipitation in Southeast Asia (Fig. 10a) show positive correlations across MSEA (R 0.4-0.6) with maximum correlations along the Vietnam coast (R 0.6-0.7). In addition, the SAMOI-N index is used to investigate meridional shifts of the active convection area associated with the monsoon. The correlation pattern between SAMOI-N and precipitation shows a dipole with increasing precipitation over North MSEA and decreasing precipitation over the Indonesian Seas with maximum positive correlations ( $R \sim 0.5-0.6)$ obtained in the northwestern part of the peninsula (Fig. 10c). SAMOI-A significantly increases during 1979-2018 (Figure 10b) indicating increasing summer monsoon intensity over MSEA during that period. Moreover, the SAMOI-N index also increases over the same period (Fig. 10d) revealing a northward shift of the monsoon centre towards northern MSEA, further enhancing Monsoon intensity there. 
Precipitation over MSEA is also associated with the major modes of natural climate variability of the tropical Pacific and Indian Oceans. One of the key challenging issues regarding the changing hydrological cycle is how to distinguish between natural low-frequency modes of large-scale variability and long-term climatic trends, and hence to properly attribute changes in the hydrological cycle to either natural variability or anthropogenic forcing. In particular, the signal of the El Nino Southern Oscillation (ENSO) is imprinted in the changing spatial patterns of long-term surface freshwater flux and salinity in the tropical Pacific and Indian oceans and may skew possible anthropogenic climatic trends (Skliris et al. 2014). Rainfall over the Southeast Asian seas has strong positive correlations to a la Nina-like SST anomaly pattern (Caesar et al. 2011; Skliris et al. 2014). The Southern Oscillation Index (SOl; https://www.ncdc.noaa.gov/teleconnections/enso/indicators/soi), which measures the intensity of ENSO with strongly positive (negative) values indicating a La Nina (EI Nino) event, is significantly correlated with annual precipitation over the Western tropical Pacific (R 0.5-0.8) as well as over MSEA (R 0.4-0.5) (Fig. 11). SOI significantly increases (more La Nina events) over the last 40 years (Fig. 11b) which may partially explain the strong large-scale precipitation increase around MSEA, in the western tropical Pacific and northeastern tropical Indian oceans (see fig. 3). The observed ocean precipitation increase around MSEA is concomitant and consistent with broad-scale decreasing ocean surface salinity over the same period (Skliris et al. 2014).

The two dominant modes of tropical Indian Ocean variability, namely the Indian Ocean Basin Mode (IOBM) and the Indian Ocean Dipole (IOD), also control climate conditions and local continental precipitation in many regions surrounding the tropical Indian Ocean. The IOBM features inter-annual basin-wide warming/cooling in the Tropical Indian Ocean and is closely associated with ENSO (Klein et al. 1999). The IOBM index is defined as the SST anomaly averaged over the tropical Indian Ocean $\left(40^{\circ} \mathrm{E}-100^{\circ} \mathrm{E}, 20^{\circ} \mathrm{S}-20^{\circ} \mathrm{N}\right)$. Inter-decadal variations of IOBM show a strong positive increase since the 1950s (Huang et al. 2019). A positive IOBM index, typically peaking in spring, is associated with increasing (decreasing) summer precipitation over North (South) MSEA although correlations are relatively low (Zhang et al. 2019). Low and statistically insignificant correlations were found here between seasonal patterns of precipitation and IOBM in most of the MSEA. On the other hand, increasing (positive) IOBM over recent decades is associated with anomalous surface warming in the tropical Indian ocean. In addition, the centre of action in the IOBM shifted from the Southeast Indian Ocean towards the Arabian Sea after the late 1970s (Sun et al. 2018). Roxy et al. (2014) identified fastest long-term warming in the Western Indian Ocean (WIO, 50-65 $\mathrm{E}, 5^{\circ} \mathrm{S}-10^{\circ} \mathrm{N}$ ) during Northern Hemisphere summer months, compared with slower warming across the rest of Indian Ocean $\left(70-100^{\circ} \mathrm{E}, 20^{\circ} \mathrm{S}-20^{\circ} \mathrm{N}\right)$. Higher positive SST anomalies are observed in the oceanic moisture sources including the Arabian Sea and Bay of Bengal (Sun et al. 2018), which may have driven the large increases in evaporation evidenced in this study, suggesting that there was potentially an increased supply of ocean moisture for MSEA precipitation over that period.

The Indian Ocean Dipole (IOD) mode is characterised by a strong east-west sea surface temperature gradient with cold anomalies off Sumatra and warm anomalies in the western Indian Ocean, accompanying wind and precipitation anomalies (Saji et al. 1999). The impact of IOD on MSEA precipitation is investigated here using the Dipole Mode Index (DMI) measuring the SST anomaly difference between the western $\left(10^{\circ} \mathrm{S}-10^{\circ} \mathrm{N}, 50^{\circ} \mathrm{E}-70^{\circ} \mathrm{E}\right)$ and the eastern $\left(10^{\circ} \mathrm{S}-0^{\circ} \mathrm{S}\right.$, $90^{\circ} \mathrm{E}-110^{\circ} \mathrm{E}$ ) parts of the tropical Indian Ocean. Positive DMI is associated with broad-scale increasing (decreasing) surface temperature and precipitation over the western (eastern) part of the tropical Indian Ocean (Fig. a). Positive DMI peaking in autumn is linked with decreasing precipitation over most of MSEA in the following summer (Zhang et al. 2019). On the other hand, Gao et al. (2019) found that extreme droughts over spring are strongly reduced throughout Vietnam and the northwestern part of the peninsula during negative IOD events, and this pattern is further accentuated when these events are also concomitant with La Nina events. There is a clear shift to predominantly positive IOD states (positive DMI) over recent decades. However as for the IOBM, the DMI correlations to MSEA precipitation obtained here (based on CPC data) are quite low $(R<0.3)$ and not statistically significant over most of the peninsula in accordance with the study of Tsai et al. (2015). We only found statistically significant negative correlations (R -0.3-0.4) between DMI and precipitation over southern parts of MSEA (sub-regions 1,3, and 5) during autumn (not shown). On the other hand, largely 
positive DMI over 1979-2018 is associated with abnormally high SSTs over the northwestern Indian Ocean and Arabian Sea. These higher SSTs may in turn have driven the observed evaporation increases in these oceanic moisture sources for MSEA precipitation over that period.

To summarise, monsoon intensification and ENSO variability with predominantly La Nina states over 1979-2018 seem to have contributed to increased precipitation over the MSEA. Together with the anthropogenically-driven increase in evaporation, the evolution of both IOBM and IOD over the last 4 decades seem to contribute to surface warming enhancing moisture availability in the oceanic moisture source regions for MSEA precipitation. It is difficult to assess the extent to which evaporation in these ocean moisture source regions has contributed to increased precipitation over MSEA due to uncertainty in long-term changes of atmospheric circulation and the associated moisture transport/convergence over MSEA that actually controls local continental precipitation. Although the present re-analyses and climate models are appropriate tools for establishing climatological mean wind and moisture flux patterns, they are still too unreliable to assess long-term trends in water cycling and in moisture transport within the lower troposphere, showing a large spread amongst them whilst also being inconsistent with observational estimates (Schanze et al 2010; Fasullo 2012; Skliris et al. 2014).

\subsection{CMIP5 $21^{\text {st }}$ century projections for mean and extreme precipitation over MSEA}

Long-term amplification of the regional hydrological cycle is further investigated, through analysis of CMIP5 coupled climate models in historical and RCP4.5/8.5 $21^{\text {st }}$ century scenario simulations. We investigated the time evolution of the multi-model (ensemble) mean precipitation averaged over MSEA and its 6 sub-regions, along with evaporation averaged over the three main oceanic moisture sources. Sperber et al. (2013) showed that CMIP5 multi-model mean (MMM) climatological summer precipitation over the historical period is quite consistent with the observed climatological precipitation pattern (from GPCP) over Southeast Asia with a pattern correlation of $\sim 0.9$. The above authors also found that the CMIP5 MMM was more skilful than the CMIP3 MMM for all diagnostics regarding the East Asian Monsoon in terms simulating pattern correlations with respect to observations, while also outperforming the individual models for both the time mean and interannual variability of monsoon rainfall.

Figure 12 shows the evolution of the ensemble mean area-averaged total annual precipitation anomalies over MSEA together with evaporation anomalies in the three major oceanic moisture sources for this region over the historical (19502005) and $21^{\text {st }}$ century (2006-2100) from RCP4.5 and RCP8.5 simulations. Interestingly, in contrast with observations, the CMIP5 historical simulations indicate a decrease in precipitation over MSEA over roughly the second half of the $20^{\text {th }}$ century (Fig. 12a). Decreasing precipitation during that period follows decreasing evaporation in the major oceanic moisture sources as opposed again to the observational/reanalysis estimates. CMIP5 projections for both RCP4.5 and RCP8.5 scenarios clearly show that over the longer timescale, strong positive trends in precipitation and evaporation emerge following the warming-driven water cycle amplification, with these changes being more pronounced in the higher warming RCP8.5 scenario. The CMIP5 ensemble mean used here shows pronounced wide-spread positive trends in annual mean and extreme precipitation over the MSEA at the end of $21^{\text {st }}$ century. This signal is spatially-coherent and quite robust throughout MSEA amongst the majority of climate models in both the RCP4.5 and RCP8.5 scenarios (e.g. Sillmann et al. 2013b). Area-averaged total annual precipitation over the whole MSEA increases by 9\% and 14\% (with respect to the historical mean) at the end of $21^{\text {st }}$ century, in RCP4.5 and RCP8.5, respectively. The evolution of precipitation over MSEA during the $21^{\text {st }}$ century closely follows that of the evaporation pattern over the tropical ocean which shows large increases in all three major oceanic moisture sources supplying moisture to the MSEA (Fig. 12b, c, d). In the RCP4.5 (RCP8.5) ensemble mean, evaporation changes over the Arabian Sea, Bay of Bengal, and South China Sea amount to $4.3 \%(8.1 \%), 5 \%(7.4 \%)$, and $4.6 \%(8.4 \%)$, respectively, at the end of $21^{\text {st }}$ century. 
Together with investigating changes in the mean precipitation regime over MSEA we also assess changes in extreme rainfall indices based on CMIP5 ensemble daily precipitation data. Results clearly demonstrate an intensification of the regional water cycle with increasing frequency and intensity of extreme precipitation events during the wet season over the $21^{\text {st }}$ century, in accordance with regional climate model results over Southeastern Asia (Ge et al. 2019). Table 3 shows trends for various extreme precipitation indices (area-averaged values over MSEA and over the 6 sub-regions considered here) in the CMIP5 ensemble mean for the historical and the $21^{\text {st }}$ century RCP4.5 and RCP8.5 simulations. As for the mean precipitation, the extreme precipitation indices show widespread significant increases throughout the peninsula (Table 3). Changes in precipitation extremes are again more pronounced in the higher warming RCP8.5 scenario. In the RCP4.5 (RCP8.5) ensemble mean the wet season precipitation (PRCPTOT) and precipitation intensity (SDII) averaged over MSEA increased by $10 \%(17 \%)$ and $10 \%(22 \%)$, respectively, at the end of the $21^{\text {st }}$ century. Also, the frequency of extreme events (averaged over MSEA) is amplifying with warming with the number of days of heavy rainfall $(>10 \mathrm{~mm} /$ day) increasing by $\sim 13 \%$, whilst the number of days of extreme rainfall $(>20 \mathrm{~mm} /$ day) increases by $\sim 34 \%$ at the end of the $21^{\text {st }}$ century in RCP8.5.

Extreme rainfall events increase at a much higher rate than wet season mean precipitation throughout the peninsula, highlighting the strongly increased flood risk in coastal regions of MSEA under global warming. These results are consistent with a warming-driven intensification of the hydrological cycle at regional level as MSEA, a "wet" tropical region strongly influenced by the Monsoon, becomes "wetter" in a warming climate. Interestingly, the duration of the dry season also significantly increases in the higher warming scenario (i.e. CDD averaged over MSEA increases by 10\% in RCP8.5), indicating an enhancement of the "wet get wetter, dry get drier" seasonal pattern with warming. However, it is also interesting to note that long-term trends in both mean and extreme precipitation obtained here, even for the highemissions RCP8.5 scenario, are lower than the recent historical 40-year trends inferred from observational rain-gauge data (CPC over 1979-2018, see section 3.1).

\section{Conclusions}

In this study we investigated large-scale coupled atmosphere/ocean processes that drive variable and extreme rainfall in the MSEA both in the past (1950s to present) and future (present to 2100). Rain-gauge data indicate large increases exceeding $50 \%$ in precipitation over the eastern coast (Vietnam) and northwest part of the MSEA over the last 40 years which seem to be linked with strong warming-driven evaporation increases over the South China Sea and Bay of Bengal/Arabian Sea, respectively. Evaporation in these oceanic moisture sources could be used as a proxy for variability and long-term trends in precipitation over MSEA as evidenced in the CMIP5 ensemble for both historical and RCP projections. Present model reanalyses and hybrid model/observationally-based datasets show better consistency amongst various products concerning ocean evaporation trends compared with rainfall trends (Skliris et al 2014). However, model and observational data uncertainties are still large, making difficult the use of such products to investigate long-term changes in oceanic moisture supply for continental precipitation.

The CMIP5 historical ensemble mean shows a decrease in precipitation over the second half of the $20^{\text {th }}$ century that is not consistent with observations, the latter indicating precipitation increases in large parts of MSEA over that period. Our results suggest that tropical ocean natural variability modes in the adjacent Pacific (ENSO) and Indian (IOD and IOB) oceans may have driven a large proportion of precipitation changes observed in MSEA over the recent historical period. Many CMIP5 models do not properly capture the intensity and time-evolution of natural variability signals, thereby misrepresenting their impact on regional hydrological cycles (e.g. Skliris et al. 2020). However, for future model projections and at the longer timescales natural variability impacts are generally smoothed out. Variability thus contributes little to long-term changes in precipitation, which are instead dominated by the anthropogenic signal of an amplifying water cycle under global warming. CMIP5 projections over the $21^{\text {st }}$ century clearly show an intensification of 
the water cycle over MSEA, with increasing frequency and intensity of extreme precipitation events over the wet season. However, projected mean and extreme precipitation trends in the CMIP5 ensemble mean are much lower than the recent historical 40-year trends over large parts of MSEA inferred from observational rain-gauge data. At the same time, in contrast with observations over the last 40 years, the dry season is also projected to increase in the higher warming scenario emphasizing the "wet get wetter, dry get drier" paradigm over time i.e. denoting an amplification of the seasonal pattern of precipitation/drought over MSEA. Importantly, the results demonstrate that the number of days of extreme rainfall and other extreme precipitation indices are increasing much more abruptly than total wet season precipitation in MSEA, and especially in flood prone regions such as the coastal areas of Vietnam and Myanmar. This underlines the increased risk of extreme flooding events in the near future, with potentially severe socio-economic impacts for these regions.

\section{Declarations}

\section{Acknowledgements}

All authors time on this paper was funded by the UK's National Environment Research Council (NERC) grant CompFlood (NE/S003150/1) and the National Foundation of Science and Technology Development, Ministry of Science and Technology of Vietnam (NAFOSTED-RCUK fund).

\section{References}

Adler RF, Huffman GJ, Chang A, Ferraro R, Xie P, Janowiak J, Rudolf B, Schneider U, Curtis S, Bolvin D, Gruber A, Susskind J, Arkin P (2003). The Version 2 Global Precipitation Climatology Project (GPCP) Monthly Precipitation Analysis (1979Present). J Hydrometeor 4:1147-1167.

Caesar J, Alexander LV, Trewin B, Tsering K, Sorany L, Vuniyayawa V, Keosavang N, Shimana A, Htay MM, Karmacharya J, Jayasinghearachchi DA, Sakkamar J, Soares E, Hung LT, Thuong LT, Hue CT, Dung NTT, Hung PV, Cuong HD, Cuong NM, Sirabaha

S (2011). Changes in temperature and precipitation extremes over the Indo-Pacific region from 1971 to 2005. International Journal of Climatology 31: 791-801.

Chen, Z., Zhou, T., Zhang, L., Chen, X., Zhang, W., \& Jiang, J. (2020). Global

land monsoon precipitation changes in CMIP6 projections. Geophysical

Research Letters, 47, e2019GL086902.

Chou C, Chiang JCH, Lan C-W, Chung C-H, Liao Y-C, Lee C-J (2013) Increase in the range between wet and dry season precipitation. Nature Geoscience 6(4):263-267

Dun $O$ (2011). Environmentally Induced Migration in the Context of Social Vulnerability.

49: 200-223. DOI: 10.1111/j.1468-2435.2010.00646.x

Durack PJ, Wijffels SE, Matear RJ (2012) Ocean salinities reveal strong global water cycle intensification during 1950 to 2000. Science 336:455-458. doi:10.1126/science.1212222

Hegerl, GC et al. (2015). Challenges in quantifying changes in the global water cycle. Bulletin of the American Meteorological Society, 96(7), 1097-1115. DOI: 10.1175/BAMS-D-13-00212.1

Page $12 / 28$ 
Fasullo J (2012). A mechanism for land-ocean contrasts in global monsoon trends in a warming climate. Clim Dyn 39:1137-1147. DOI 10.1007/s00382-011-1270-3

Gao Q-G, Sombutmounvong V, Xionag L, Lee J-H, Kim J-S (2019). Analysis of Drought-Sensitive Areas and Evolution Patterns through Statistical Simulations of the Indian Ocean Dipole Mode. Water 11: 1302. doi:10.3390/w11061302

Ge F, Zhu S, Peng T, Zhao Y, Sielmann F, Fraedrich K, Zhi X, Liu X, Tang W, Ji L (2019). Risks of precipitation extremes over Southeast Asia: does $1.5^{\circ} \mathrm{C}$ or $2^{\circ} \mathrm{C}$ global warming make a difference? Environ. Res. Lett. 14: 044015

Good SA, Martin MJ, Rayner NA (2013) Quality controlled ocean temperature and salinity profiles and monthly objective analyses with uncertainty estimates. J Geophys Res Oceans 118:6704-6716

Held IM, Soden BJ (2006) Robust responses of the hydrological cycle to global warming. J Clim 19:5686-5699. doi:10.1175/JCLI3990.1.

Hersbach H, et al. (2020). The global ERA5 reanalysis. Q J R Meteorol Soc. 146:1999-2049. doi: 10.1002/qj.3803

Huang Y, Wu B, Li T, Liu B, Zhou T (2019). Interdecadal Indian Ocean Basin Mode Driven by Interdecadal Pacific Oscillation: A Season-Dependent Growth Mechanism. J Clim 32 (7): 2057-2073. doi: 10.1175/JCLI-D-18-0452.1

Klein SA, Soden BJ, Lau N-C (1999) Remote sea surface variations during ENSO: evidence for a tropical atmospheric bridge. J Clim 12:917-932.

Liu C, Allan RP (2012) Multi-satellite observed responses of precipitation and its extremes to interannual climate variability. J Geophys Res 117:D03101. doi:10.1029/2011JD016568

Liu C, Allan RP, Huffman GJ (2012) Co-variation of temperature and precipitation in CMIP5 models and satellite observations. Geophys Res Lett 39:L13803. doi:10.1029/2012GL052093

Nguyen et al. 2014. Variations of surface temperature and rainfall in Vietnam from 1971 to 2010. Int. J. Climatol. 34 : 249-264.

Nicholls RJ, Wong PP, Burkett VR, Codignotto JO, Hay, JE, McLean RF, Ragoonaden S, Woodroffe CD (2007) Coastal systems and low-lying areas. In: Climate Change 2007: Impacts, Adaptation and Vulnerability. Contribution ofWorking Group II to the Fourth Assessment Report of the Intergovernmental Panel on Climate Change, [Parry ML, Canziani OF, Palutikof JP, van der Linden PJ, and Hanson CE (eds.)]. Cambridge University Press, Cambridge, UK and New York, NY, USA, pp. 315-356.

O'Gorman PA (2015) Precipitation extremes under climate change. Curr Clim Change Rep 1:49-59. DOI 10.1007/s40641015-0009-3

Roxy MK, Ritika K, Terray P, Masson S (2014). The Curious Case of Indian Ocean Warming. J Clim 27:8501-8509.

Saji NH, Goswami BN, Vinayachandran PN, Yamagata T (1999) A dipole

mode in the tropical Indian Ocean. Nature 401(6):360-363

Andrew P Schurer AP, Ballinger AP, Friedman AR, Hegerl GC (2020) Human influence strengthens the contrast between tropical wet and dry regions. Environ Res Lett 15: 104026.

Sillmann J, Kharin VV, Zhang X, Zwiers FW, Bronaugh D (2013a) Climate extremes indices in the CMIP5 multimodel ensemble: Part 1. Model evaluation in the present climate. J Geophys Res Atmos 118: 1716-1733. 
Doi:10.1002/jgrd.50203

Sillmann J, Kharin VV, Zhang X, Zwiers FW, Bronaugh D (2013b) Climate extremes indices in the CMIP5 multimodel ensemble: Part 2. Future climate projections, J Geophys Res Atmos 118: 2473-2493. Doi:10.1002/jgrd.50188

Skliris N., Marsh R, Josey SA, Good SA, Liu C, Allan RP (2014). Salinity changes in the World Ocean since 1950 in relation to changing surface freshwater fluxes. Clim Dyn 43: 709-736.

Skliris N, Zika JD, Nurser G, Josey SA, Marsh R (2016). Global water cycle amplifying at less than the Clausius-Clapeyron rate. Scientific Reports 6, 38752. doi: 10.1038/srep38752.

Skliris N, Marsh R, Mecking J, Zika JD (2020). Changing water cycle and freshwater transports in the Atlantic Ocean in observations and CMIP5 models. Clim Dyn. DOI: 10.1007/s00382-020-05261-y

Sperber KR, Annamalai H, Kang I-S, Kitoh A, Moise A, Turner A, Wang B, Zhou T (2013). The Asian summer monsoon: an intercomparison of CMIP5 vs. CMIP3 simulations of the late 20th century. Clim Dyn 41:2711-2744. DOI 10.1007/s00382012-1607-6

Sun, B., Li, H., \& Zhou, B. (2019). Interdecadal variation of Indian Ocean basin mode and the impact on Asian summer climate. Geophysical Research Letters, 46: 12,388-12,39. DOI: 10.1029/2019GL085019

Sun B, Wang H (2015). Analysis of the major atmospheric moisture sources affecting

three sub-regions of East China. Int. J. Climatol. 35: 2243-2257.

Taylor KE, Stouffer RJ, Meehl GA (2012). An overview of CMIP5 and the experiment design. Bull. Amer. Meteor. Soc. 93:485-498.

Tsai C, Behera SK, Waseda T (2015). MSEA Monsoon indices. Scientific Reports 5: 8107, DOI: 10.1038/srep08107.

van der Ent RJ, Savenije HHG (2013). Oceanic sources of continental precipitation and the correlation with sea surface temperature. Water Resour. Res 49:3993-4004. doi:10.1002/wrcr.20296

Wang Z, Chang, C-P (2012). A numerical study of the interaction between the largescale monsoon circulation and orographic precipitation over South and Southeast Asia. J. Clim. 25: 2440-2455.

Wu G, Liu Y, He B, Bao Q, Duan A Jin, F-F (2012). Thermal controls on the Asian summer monsoon Sci. Rep. 2: 404

Yang J, Liu Q, Liu Z, Wu L, Huang F (2009). Basin mode of Indian Ocean sea surface temperature and Northern Hemisphere circumglobal teleconnection. Geophys Res Lett 36:L19705, doi:10.1029/2009GL039559.

Yanai M, Wu G-X (2006). Effects of the Tibetan Plateau. Chapter 13, The Asian Monsoon (eds Wang, B. et al.). Springer, Chichester.

Yatagai A et al 2012 APHRODITE: constructing a long-term daily gridded precipitation dataset for Asia based on a dense network of rain gauges Bull. Am. Meteorol. Soc. 93 1401-15.

Yu L, Jin X, Weller RA (2008) Multidecade global flux datasets from the Objectively Analyzed Air-sea Fluxes (OAFlux) Project: Latent and Sensible Heat Fluxes, Ocean Evaporation and Related Surface Meteorological Variables. OAFlux Project Technical Report (OA2008-01), Woods Hole Oceanographic Institution. 
Zhou, S., Huang, P., Huang, G., \& Hu, K. (2019). Leading source and constraint on the systematic spread of the changes in East Asian and western North Pacific summer monsoon. Environmental Research Letters, 14, 124059.

https://doi.org/10.1088/1748-9326/ab547c

Zika JD, Skliris N, Blaker AT, Marsh R, Nurser AJG, Josey SA (2018) Improved estimates of water cycle change from ocean salinity: the key role of ocean warming. Environ Res Lett 13(7):1-10. DOI: 10.1088/1748-9326/aace4 2

\section{Tables}

Table 1. Precipitation annual and seasonal trends (mm/day/40yrs) over 1979-2018 averaged over MSEA and the 6 subregions considered in this study based on the Global Unified Gauge-Based Analysis of Daily Precipitation - Climate Prediction centre (CPC). Symbol ' $*$ ' denotes trends that are not statistically significant at the 95\% confidence interval. Values in parentheses indicate percentage of change (w.r.t the climatological mean) over 1979-2018.

\begin{tabular}{|llllll|}
\hline Region/Period & Annual & Winter (DJF) & Spring (MAM) & Summer (JJA) & Autumn (SON) \\
\hline MSEA & $1.00(24 \%)$ & $0.98(73 \%)$ & $0.74(25 \%)$ & $0.97(14 \%)^{\star}$ & $0.78(15 \%)$ \\
\hline 1. S. Vietnam & $1.87(60 \%)$ & $1.45(135 \%)$ & $1.11(76 \%)$ & $2.79(78 \%)$ & $2.04(35 \%)$ \\
\hline 2. N. Vietnam & $2.22(55 \%)$ & $2.03(130 \%)$ & $0.82(37 \%)$ & $2.73(52 \%)$ & $3.37(49 \%)$ \\
\hline 3. C. MSEA & $-0.04(1 \%)^{\star}$ & $0.21(56 \%)$ & $0.23(7 \%)$ & $-0.60(9 \%)^{*}$ & $-0.04(1 \%)^{\star}$ \\
\hline 4. N. MSEA & $-0.07(3 \%)^{\star}$ & $0.09(21 \%)^{\star}$ & $0.17(8 \%)^{\star}$ & $-0.14(2 \%)^{*}$ & $-0.34(12 \%)^{\star}$ \\
\hline 5. S. Myanmar & $0.42(8 \%)^{\star}$ & $1.37(131 \%)$ & $0.82(21 \%)^{\star}$ & $-0.87(9 \%)^{*}$ & $0.40(6 \%)^{\star}$ \\
\hline 6. N. Myanmar & $1.69(53 \%)$ & $0.02(5.5 \%)^{\star}$ & $1.80(73 \%)$ & $3.49(48 \%)$ & $1.18(45 \%)$ \\
\hline
\end{tabular}

Table 2. Trends in Extreme Precipitation Indices averaged over MSEA and the 6 sub-regions considered in this study based on the Global Unified Gauge-Based Analysis of Daily Precipitation - Climate Prediction Centre (CPC) over 19782018. Symbol ' $*$ ' denotes trends that are not statistically significant at the $95 \%$ confidence interval. Values in parentheses indicate percentage of change (w.r.t the climatological mean) over 1979-2018.

\begin{tabular}{|llllll|}
\hline Region & $\begin{array}{l}\text { PRCPTOT } \\
(\mathrm{mm} / 40 \mathrm{yrs})\end{array}$ & $\begin{array}{l}\text { SDII } \\
(\mathrm{mm} / \text { day/40yrs })\end{array}$ & $\begin{array}{l}\text { CDD } \\
\text { (days/40yrs) }\end{array}$ & $\begin{array}{l}\text { R10mm } \\
\text { (days/40yrs) }\end{array}$ & $\begin{array}{l}\text { R20mm } \\
\text { (days/40yrs) }\end{array}$ \\
\hline MSEA & $162(19 \%)$ & $0.26(3 \%)^{*}$ & $-3.5(11 \%)^{*}$ & $4.5(18 \%)$ & $2.3(22 \%)$ \\
\hline $\begin{array}{l}\text { 1. S. } \\
\text { Vietnam }\end{array}$ & $381(57 \%)$ & $-0.42(4 \%)^{*}$ & $-27.6(69 \%)$ & $12.6(67 \%)$ & $5.4(62 \%)$ \\
\hline $\begin{array}{l}\text { 2. N. } \\
\text { Vietnam }\end{array}$ & $466(46 \%)$ & $2.00(17 \%)$ & $-15.2(59 \%)$ & $12.9(45 \%)$ & $7.2(54 \%)$ \\
\hline $\begin{array}{l}\text { 3. C. MSEA } \\
\text { 4. N. MSEA }\end{array}$ & $-13(1 \%)^{*}$ & $0.09(1 \%)^{*}$ & $3.0(6 \%)^{*}$ & $-0.3(1 \%)^{*}$ & $-0.1(1 \%)^{*}$ \\
\hline $\begin{array}{l}\text { 5. S. } \\
\text { Myanmar }\end{array}$ & $60(9 \%)^{*}$ & $-3.2(29 \%)$ & $-6.1(26 \%)$ & $2.5(12 \%)^{*}$ & $0.5(5 \%)^{*}$ \\
\hline $\begin{array}{l}\text { 6. N. } \\
\text { Myanmar }\end{array}$ & $538(54 \%)$ & $3.44(35 \%)$ & $-0.4(1 \%)$ & $13.7(47 \%)$ & $7.6(56 \%)$ \\
\hline
\end{tabular}


Table 3. Trends in Extreme Precipitation Indices (PRCPTOT, SDII, CDD, R10mm, R20mm) averaged over MSEA and the 6 sub-regions considered in this study based on the CMIP5 ensemble mean in the RCP4.5 and RCP8.5 scenario simulations. Values in parentheses indicate percentage of change (w.r.t the historical mean). Symbol ' $*$ ' denotes trends that are not statistically significant at the $95 \%$ confidence interval.

\begin{tabular}{|c|c|c|c|c|c|c|c|c|c|c|}
\hline \multirow[t]{2}{*}{ Region } & \multicolumn{2}{|c|}{$\begin{array}{l}\text { PRCPTOT } \\
\text { mm/cent. }\end{array}$} & \multicolumn{2}{|c|}{$\begin{array}{l}\text { SDII } \\
\text { mm/day/cent. }\end{array}$} & \multicolumn{2}{|c|}{$\begin{array}{l}\text { CDD } \\
\text { days/cent. }\end{array}$} & \multicolumn{2}{|c|}{$\begin{array}{l}\text { R10mm } \\
\text { days/cent. }\end{array}$} & \multicolumn{2}{|c|}{$\begin{array}{l}\text { R20mm } \\
\text { days/cent. }\end{array}$} \\
\hline & RCP4.5 & RCP8.5 & RCP4.5 & RCP8.5 & RCP4.5 & RCP8.5 & RCP4.5 & RCP8.5 & $\mathrm{RCP} 4.5$ & RCP8.5 \\
\hline MSEA & $\begin{array}{l}162 \\
(10 \%)\end{array}$ & $\begin{array}{l}241 \\
(17 \%)\end{array}$ & $\begin{array}{l}0.90 \\
(10 \%)\end{array}$ & $\begin{array}{l}1.98 \\
(22 \%)\end{array}$ & $\begin{array}{l}-1.1 \\
(2 \%)^{*}\end{array}$ & $\begin{array}{l}4.1 \\
(8 \%)\end{array}$ & $\begin{array}{l}4.7 \\
(10 \%)\end{array}$ & $\begin{array}{l}6.2 \\
(13 \%)\end{array}$ & $\begin{array}{l}3.0 \\
(20 \%)\end{array}$ & $\begin{array}{l}5.1 \\
(34 \%)\end{array}$ \\
\hline $\begin{array}{l}\text { 1. South } \\
\text { Vietnam }\end{array}$ & $\begin{array}{l}106 \\
(6 \%)\end{array}$ & $\begin{array}{l}223 \\
(13 \%)\end{array}$ & $\begin{array}{l}0.53 \\
(6 \%)\end{array}$ & $\begin{array}{l}1.38 \\
(16 \%)\end{array}$ & $\begin{array}{l}1.5 \\
(4 \%)^{*}\end{array}$ & $\begin{array}{l}4.5 \\
(11 \%)\end{array}$ & $\begin{array}{l}3.7 \\
(6 \%)\end{array}$ & $\begin{array}{l}7.7 \\
(13 \%)\end{array}$ & $\begin{array}{l}2.1 \\
(13 \%)\end{array}$ & $\begin{array}{l}5.0 \\
(31 \%)\end{array}$ \\
\hline $\begin{array}{l}\text { 2. North } \\
\text { Vietnam }\end{array}$ & $\begin{array}{l}115 \\
(9 \%)\end{array}$ & $\begin{array}{l}161 \\
(12 \%)\end{array}$ & $\begin{array}{l}0.75 \\
(9 \%)\end{array}$ & $\begin{array}{l}1.63 \\
(19 \%)\end{array}$ & $\begin{array}{l}-1.2 \\
(3 \%)^{*}\end{array}$ & $\begin{array}{l}4.3 \\
(10 \%)\end{array}$ & $\begin{array}{l}3.6 \\
(9 \%)\end{array}$ & $\begin{array}{l}5.1 \\
(12 \%)\end{array}$ & $\begin{array}{l}2.3 \\
(19 \%)\end{array}$ & $\begin{array}{l}3.9 \\
(33 \%)\end{array}$ \\
\hline $\begin{array}{l}\text { 3. Central } \\
\text { MSEA }\end{array}$ & $\begin{array}{l}131 \\
(9 \%)\end{array}$ & $\begin{array}{l}212 \\
(12 \%)\end{array}$ & $\begin{array}{l}0.74 \\
(8 \%)\end{array}$ & $\begin{array}{l}1.66 \\
(18 \%)\end{array}$ & $\begin{array}{l}-1.2 \\
(2 \%)^{*}\end{array}$ & $\begin{array}{l}2.6 \\
(5 \%)\end{array}$ & $\begin{array}{l}4.2 \\
(8 \%)\end{array}$ & $\begin{array}{l}6.7 \\
(13 \%)\end{array}$ & $\begin{array}{l}2.8 \\
(22 \%)\end{array}$ & $\begin{array}{l}5.1 \\
(41 \%)\end{array}$ \\
\hline $\begin{array}{l}\text { 4. North } \\
\text { MSEA }\end{array}$ & $\begin{array}{l}182 \\
(13 \%)\end{array}$ & $\begin{array}{l}266 \\
(19 \%)\end{array}$ & $\begin{array}{l}1.01 \\
(11 \%)\end{array}$ & $\begin{array}{l}2.24 \\
(24 \%)\end{array}$ & $\begin{array}{l}-1.61 \\
(3 \%)\end{array}$ & $\begin{array}{l}3.45 \\
(6 \%)\end{array}$ & $\begin{array}{l}4.9 \\
(10 \%)\end{array}$ & $\begin{array}{l}6.4 \\
(13 \%)\end{array}$ & $\begin{array}{l}3.3 \\
(23 \%)\end{array}$ & $\begin{array}{l}5.5 \\
(38 \%)\end{array}$ \\
\hline $\begin{array}{l}\text { 5. South } \\
\text { Myanmar }\end{array}$ & $\begin{array}{l}230 \\
(14 \%)\end{array}$ & $\begin{array}{l}277 \\
(17 \%)\end{array}$ & $\begin{array}{l}1.3 \\
(12 \%)\end{array}$ & $\begin{array}{l}2.3 \\
(21 \%)\end{array}$ & $\begin{array}{l}-2.6 \\
(3 \%)^{*}\end{array}$ & $\begin{array}{l}2.7 \\
(3 \%)^{\star}\end{array}$ & $\begin{array}{l}6.3 \\
(11 \%)\end{array}$ & $\begin{array}{l}6.4 \\
(12 \%)\end{array}$ & $\begin{array}{l}4.2 \\
(23 \%)\end{array}$ & $\begin{array}{l}5.0 \\
(29 \%)\end{array}$ \\
\hline $\begin{array}{l}\text { 6. North } \\
\text { Myanmar }\end{array}$ & $\begin{array}{l}204 \\
(12 \%)\end{array}$ & $\begin{array}{l}354 \\
(21 \%)\end{array}$ & $\begin{array}{l}1.1 \\
(10 \%)\end{array}$ & $\begin{array}{l}2.5 \\
(24 \%)\end{array}$ & $\begin{array}{l}0.3 \\
(0 \%)^{*}\end{array}$ & $\begin{array}{l}4.9 \\
(9 \%)\end{array}$ & $\begin{array}{l}4.6 \\
(9 \%)\end{array}$ & $\begin{array}{l}6.6 \\
(13 \%)\end{array}$ & $\begin{array}{l}3.1 \\
(16 \%)\end{array}$ & $\begin{array}{l}5.8 \\
(30 \%)\end{array}$ \\
\hline
\end{tabular}

\section{Figures}



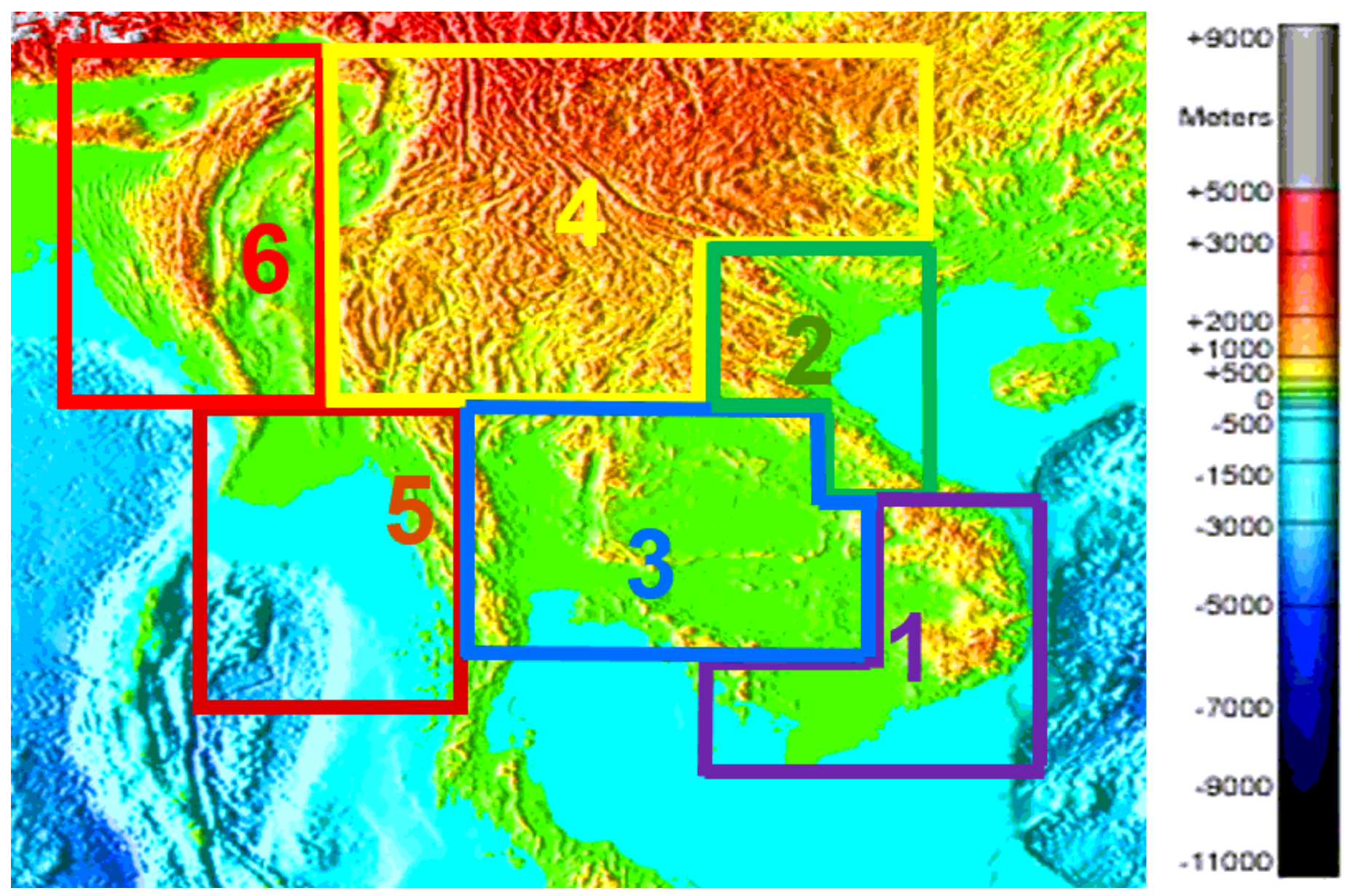

Figure 1

Mainland Southeast Asia topographical map (National Oceanic and Atmospheric Administration, http://www.ngdc.noaa.gov/mgg/image/2minrelief.html) based on ETOPO2v2 topography/bathymetry 2-minute dataset. The 6 sub-regions for which area-averaged mean and extreme precipitation changes are investigated here are also depicted: (1) South Vietnam, (2) North Vietnam, (3) Central MSEA, (4) North MSEA, (5) South Myanmar, (6) North Myanmar 
(a)

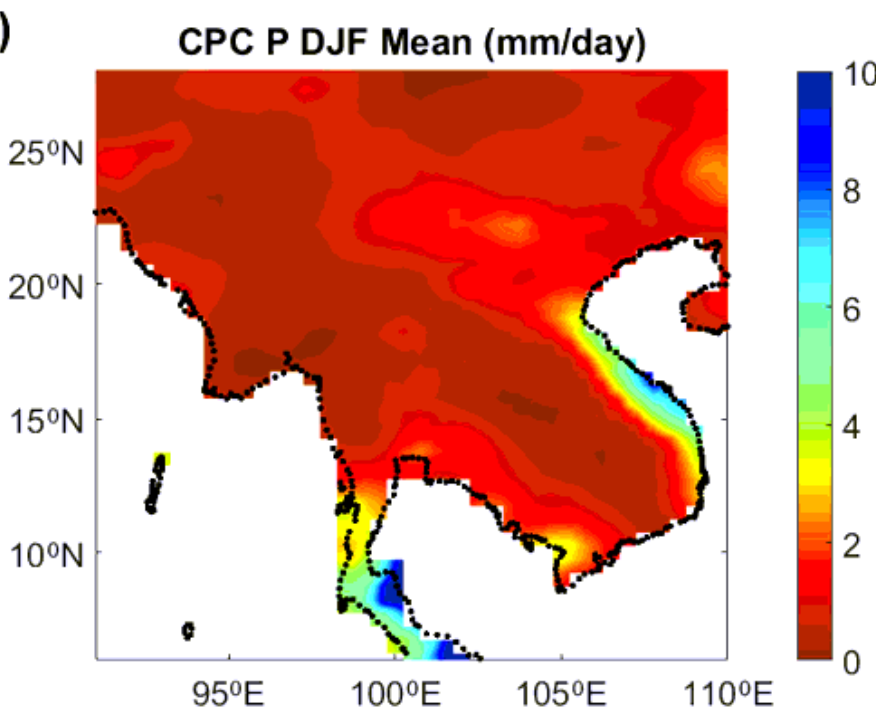

(c)

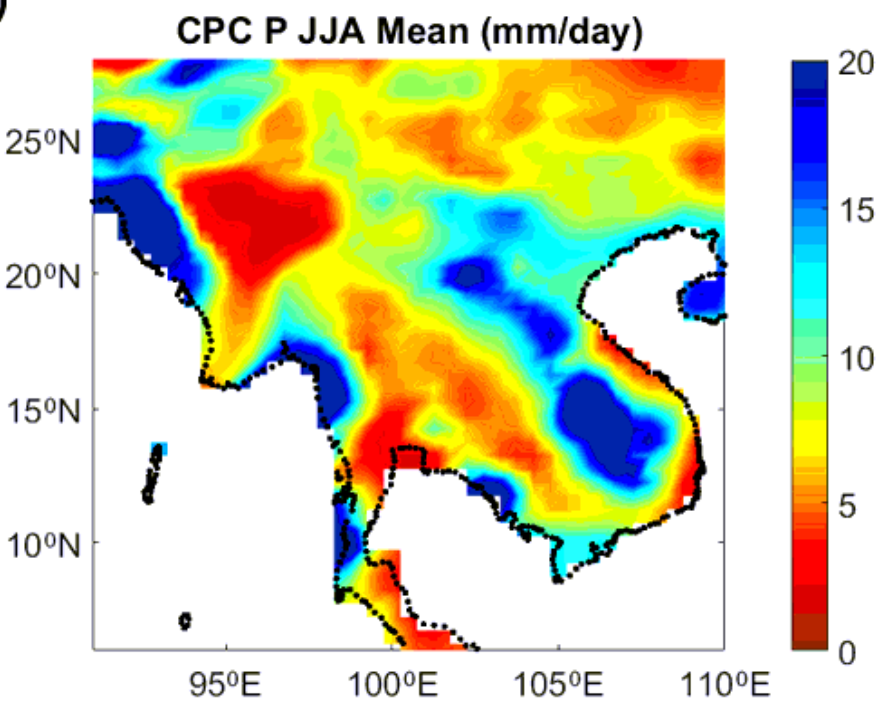

(b)

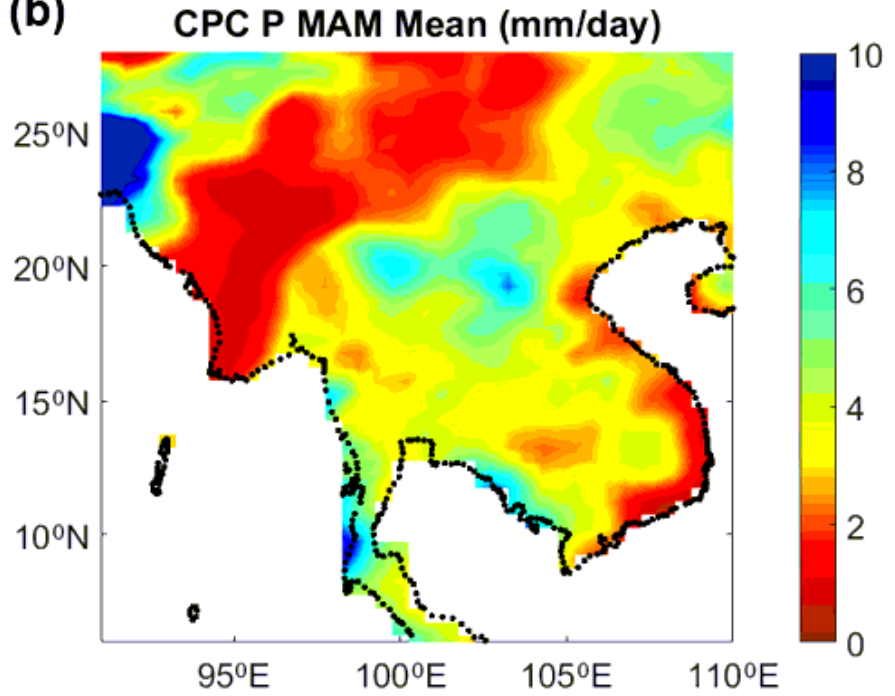

(d)

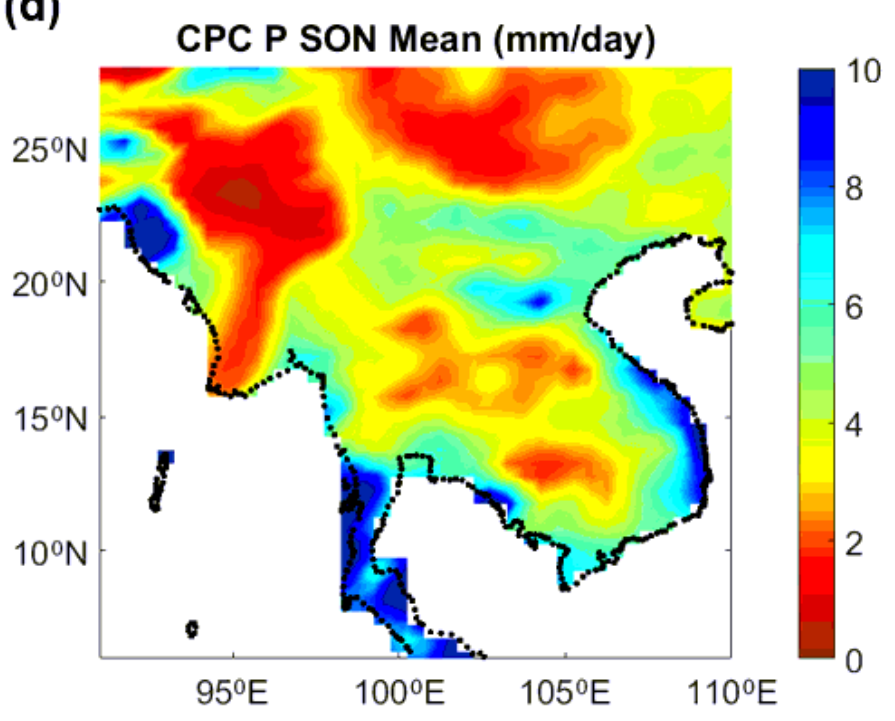

Figure 2

Climatological mean seasonal precipitation patterns over MSEA based on the Global Unified Gauge-Based Analysis of Daily Precipitation - Climate Prediction Centre (CPC) dataset: (a) Winter (Dec-Feb); (b) Spring (Mar-May); (c) Summer (Jun-Aug); (d) Autumn (Sep-Nov). 
(a)

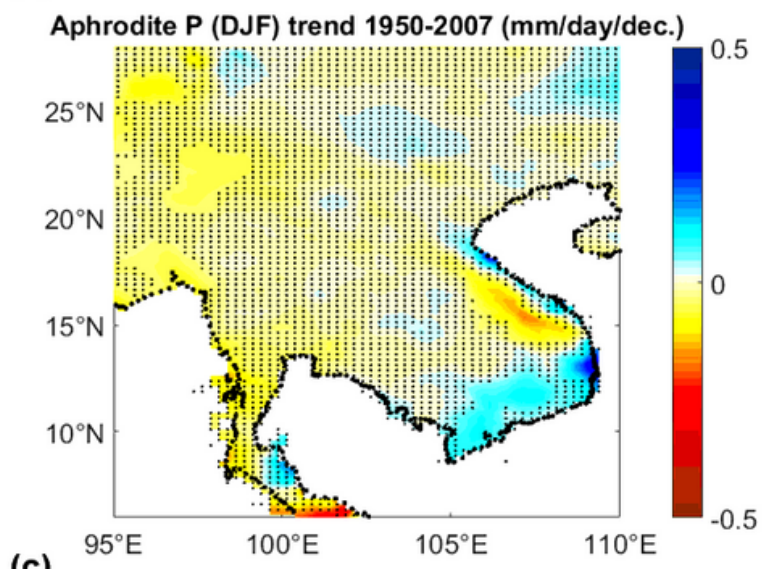

(c)

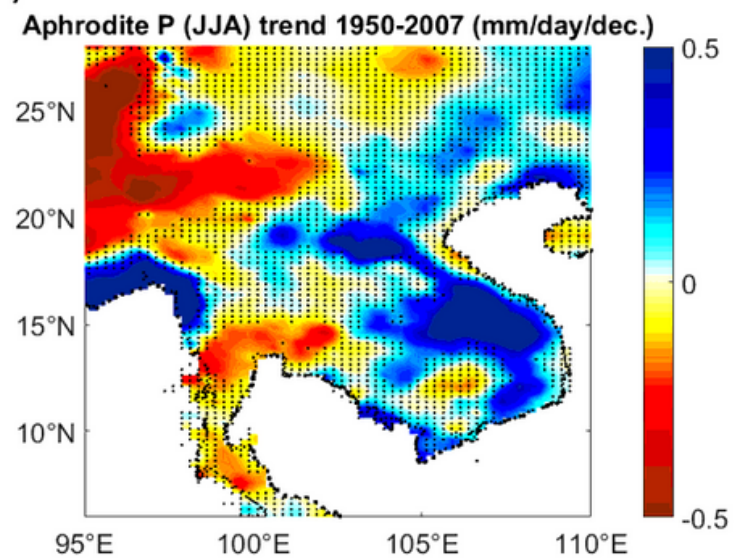

(b)

Aphrodite P (MAM) trend 1950-2007 (mm/day/dec.)

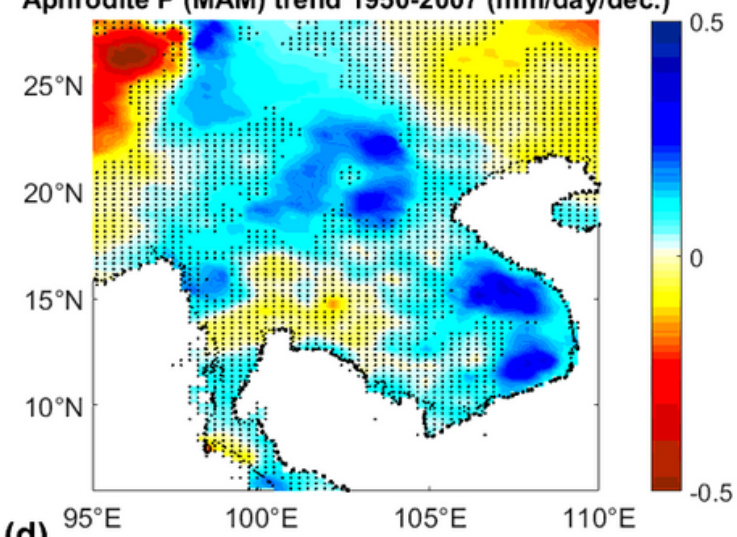

Aphrodite P (SON) trend 1950-2007 (mm/day/dec.)

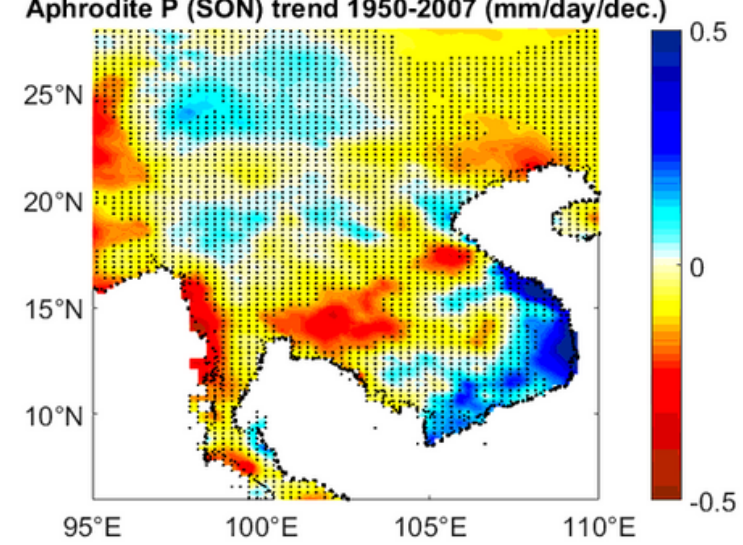

Figure 3

Seasonal precipitation trends (mm/day/decade over 1950-2007 based on the rain-gauge-based APHRODITE dataset: (a) Winter (Dec-Feb); (b) Spring (Mar-May); (c) Summer (Jun-Aug); (d) Autumn (Sep-Nov). Regions where the linear trend is not significant at the $95 \%$ confidence interval are stippled. 
(a)

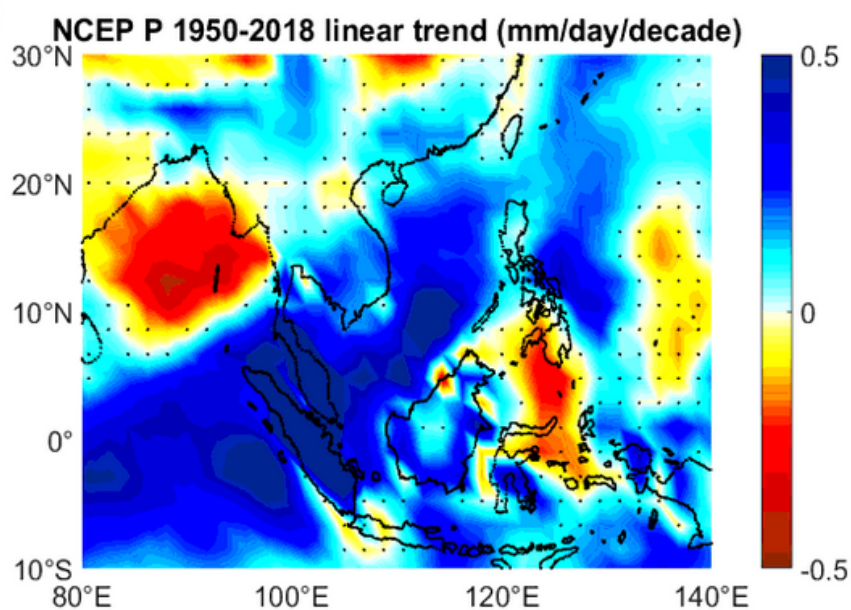

(b)



(c)

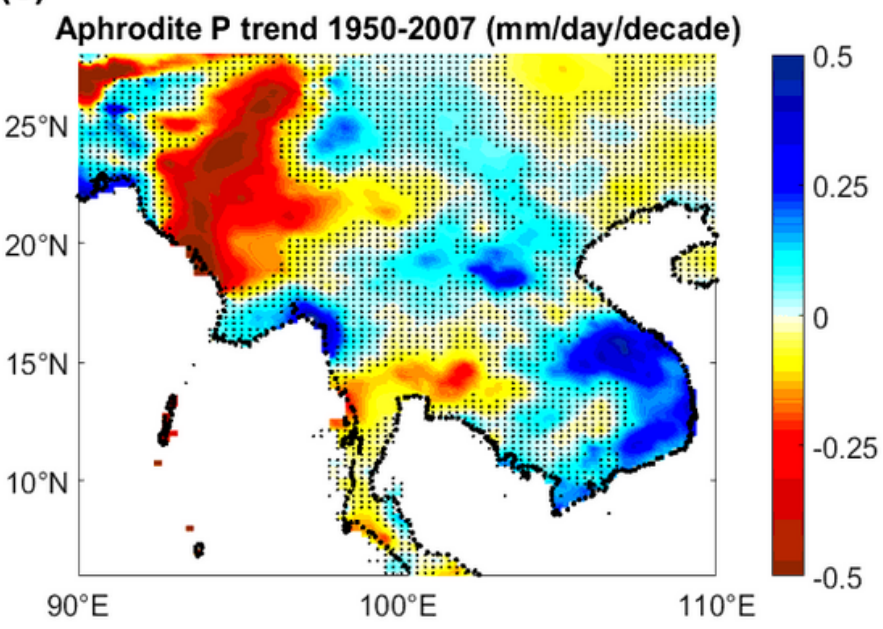

Figure 4

Annual precipitation linear trends (mm/day/decade): (a) NCEP/NCAR over 1950-2018; (b) NCEP/NCAR over 1950-2007; (c) APHRODITE over 1950-2007. Regions where the linear trend is not significant at the $95 \%$ confidence interval are stippled. 
(a)

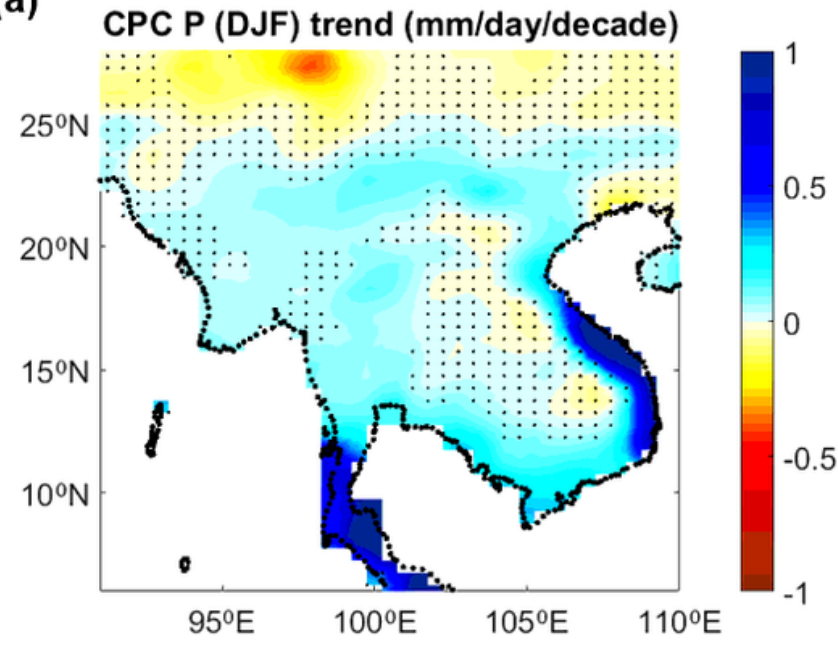

(c)

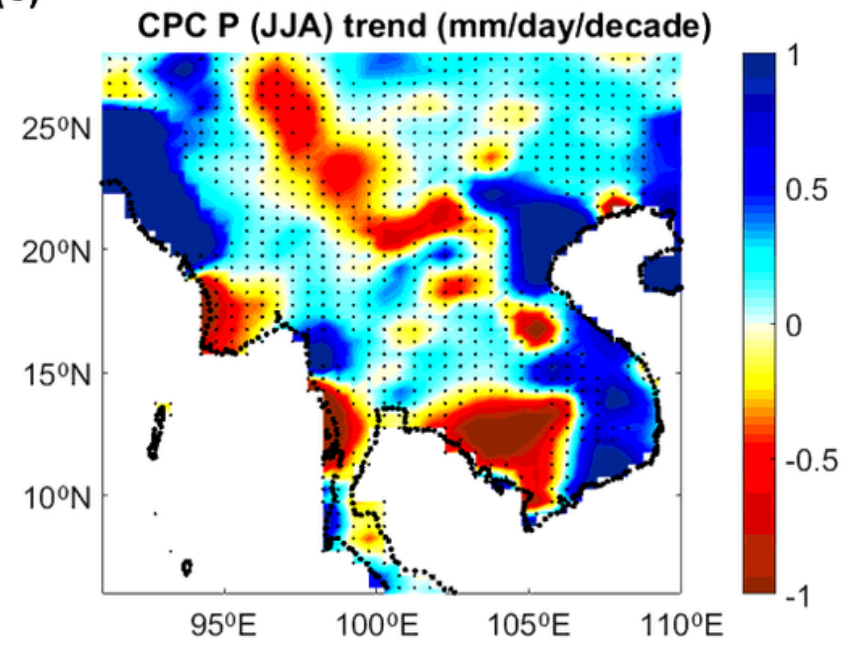

(b)

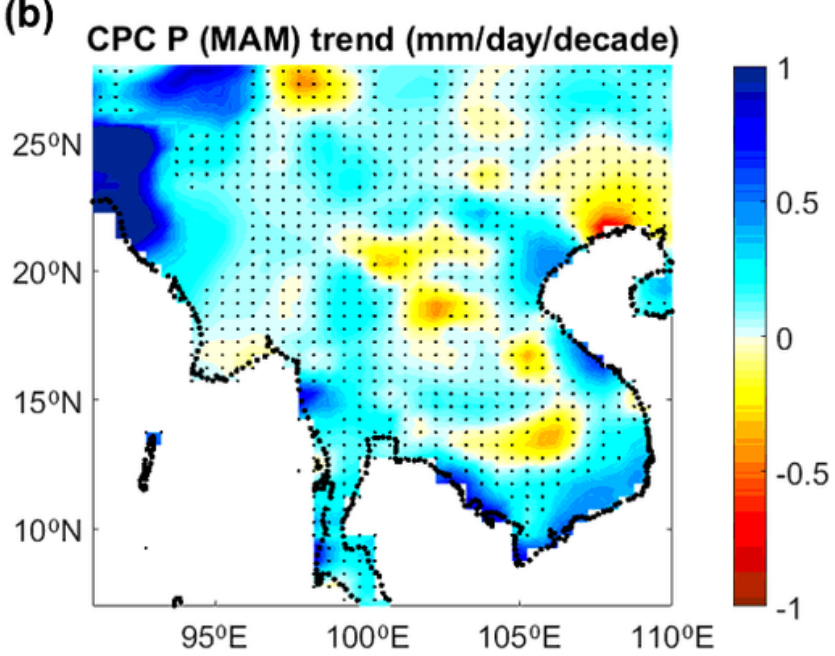

(d)

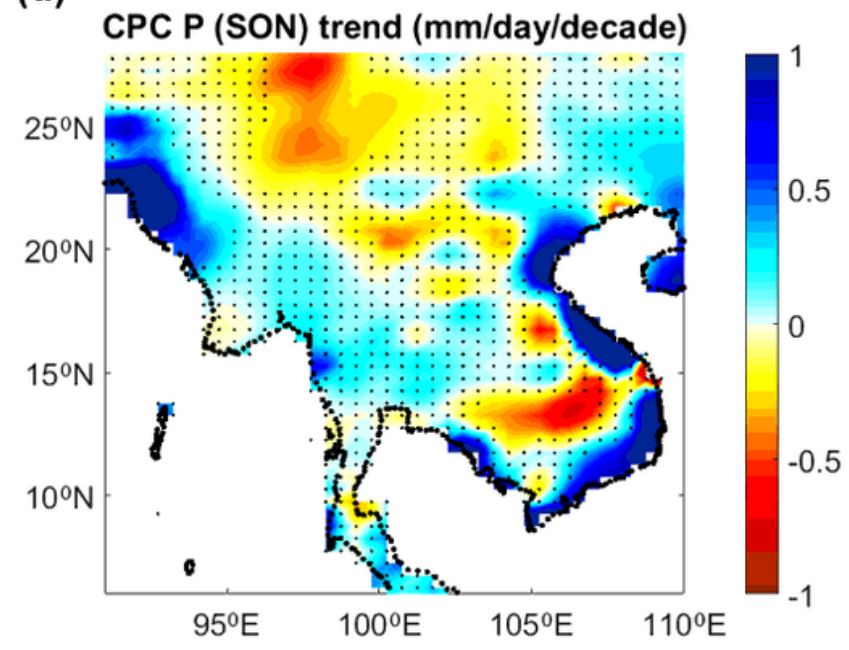

Figure 5

Seasonal precipitation trends (mm/day/decade) over 1979-2018 from the Global Unified Gauge-Based Analysis of Daily Precipitation - Climate Prediction Centre (CPC) dataset: (a) Winter (Dec-Feb); (b) Spring (Mar-May); (c) Summer (JunAug); (d) Autumn (Sep-Nov). Regions where the linear trend is not significant at the $95 \%$ confidence interval are stippled. 

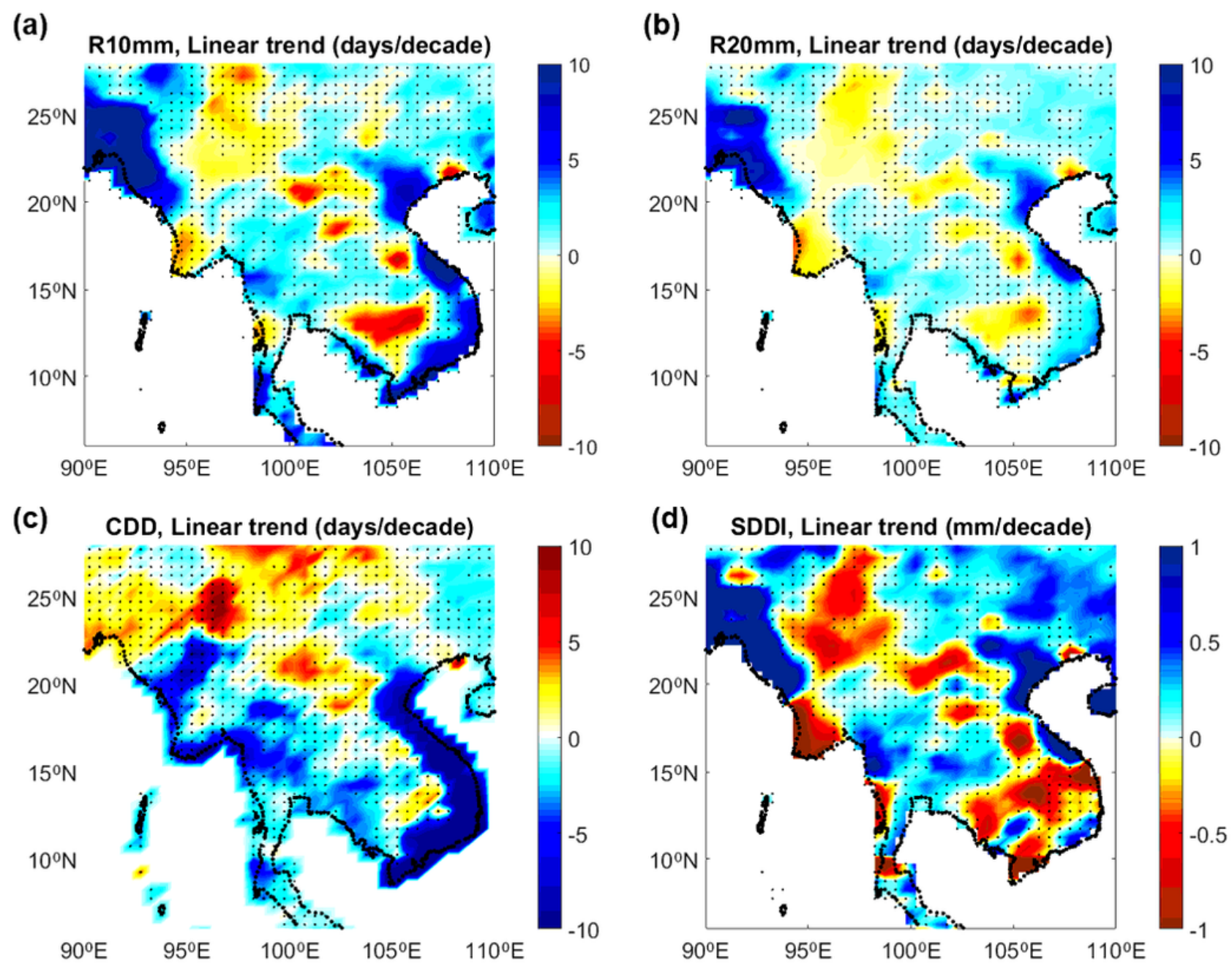

Figure 6

Trends over 1979-2018 in extreme precipitation indices from the Global Unified Gauge-Based Analysis of Daily Precipitation - Climate Prediction Centre (CPC) dataset. (a) R10mm: Number of days of heavy precipitation (P>10mm), (b) R20mm: Number of days of very heavy precipitation ( $P>20 \mathrm{~mm}),(c)$ CDD: Number of Consecutive Dry Days, (d) SDII: Simple daily precipitation intensity. Regions where the linear trend is not significant at the $95 \%$ confidence interval are stippled. 
(a)



(c)

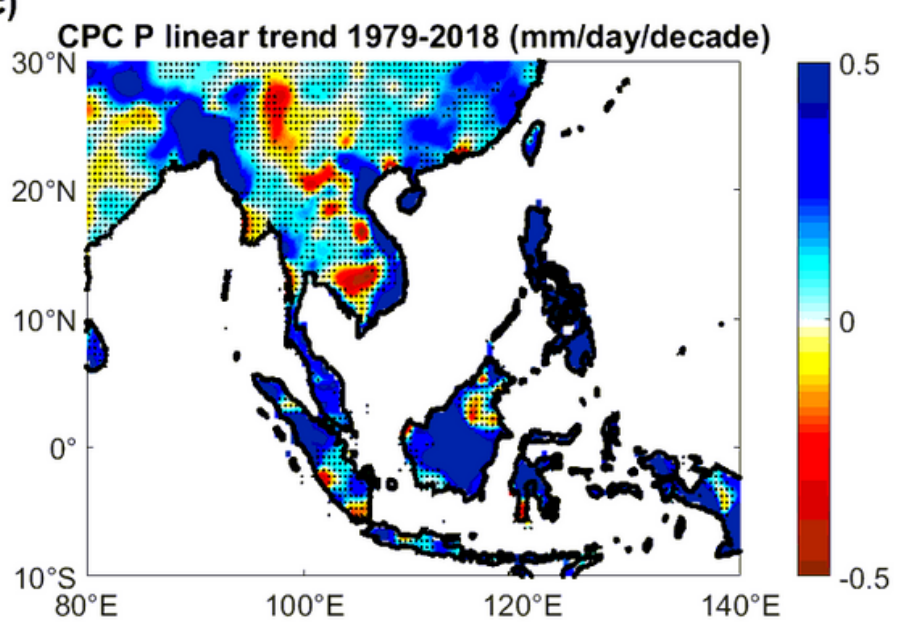

(b)

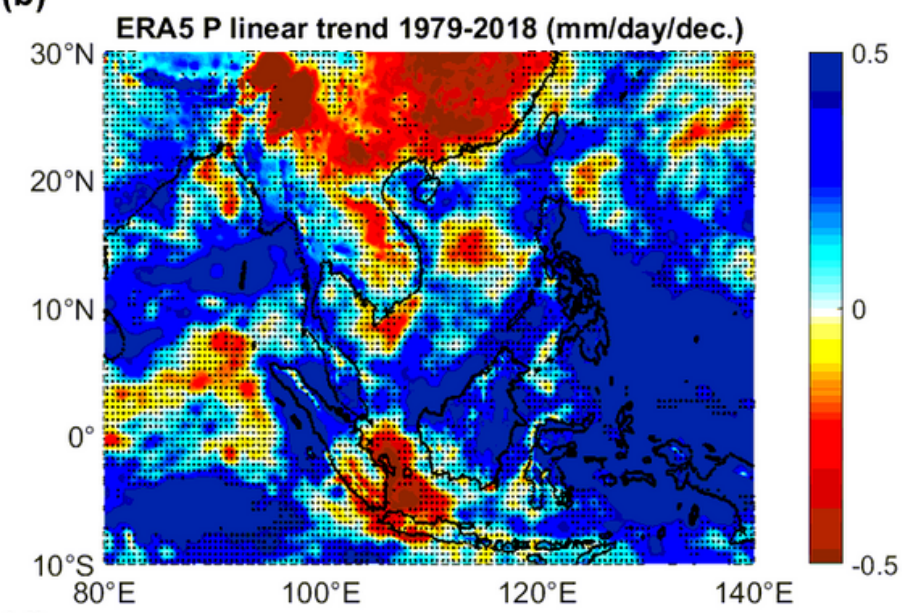

(d)

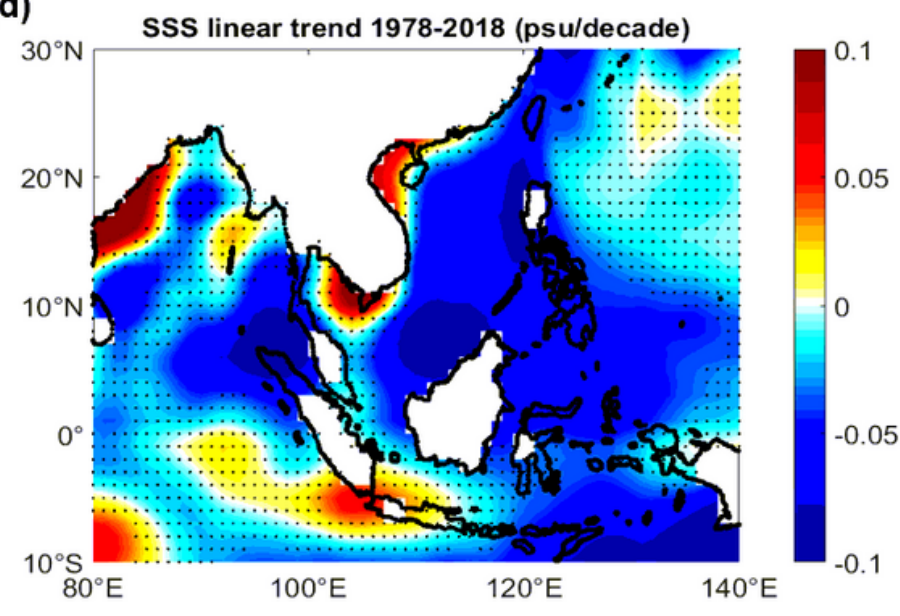

\section{Figure 7}

Linear trends over 1979-2018 in (a) GPCP Precipitation; (b) ERA5 Precipitation; (c) CPC Precipitation; (d) En4 Near Surface Salinity. Regions where the linear trend is not significant at the $95 \%$ confidence interval are stippled. 
(a) NCEP E 1950-2018 linear trend ( $\mathrm{mm} /$ day/dec.)

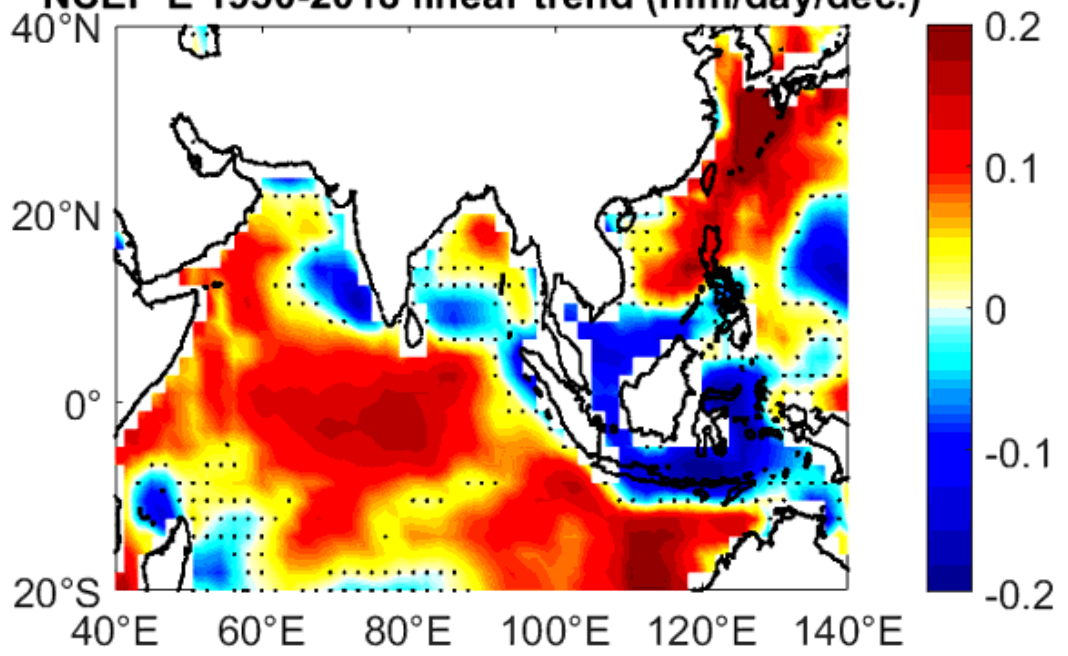

(b) OAFlux E 1958-2018 linear trend ( $\mathrm{mm} /$ day/dec.)

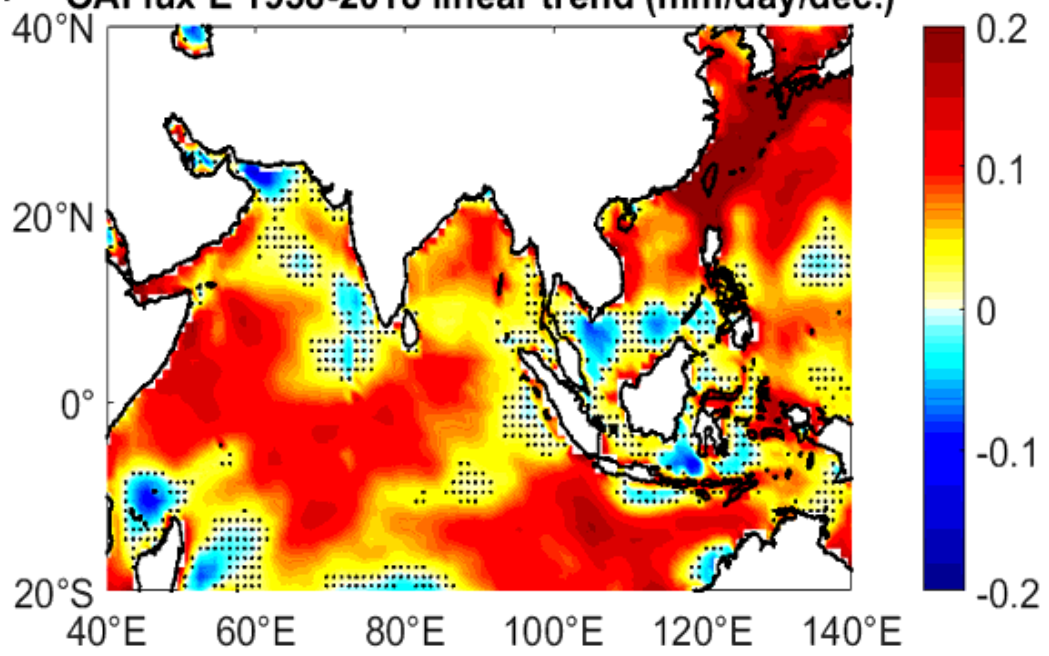

Figure 8

Linear trends in evaporation (mm/day/decade) from (a) OAFlux (1958-2018); (b) NCEP/NCAR (1950-2018). Regions where the linear trend is not significant at the $95 \%$ confidence interval are stippled. 
(a)

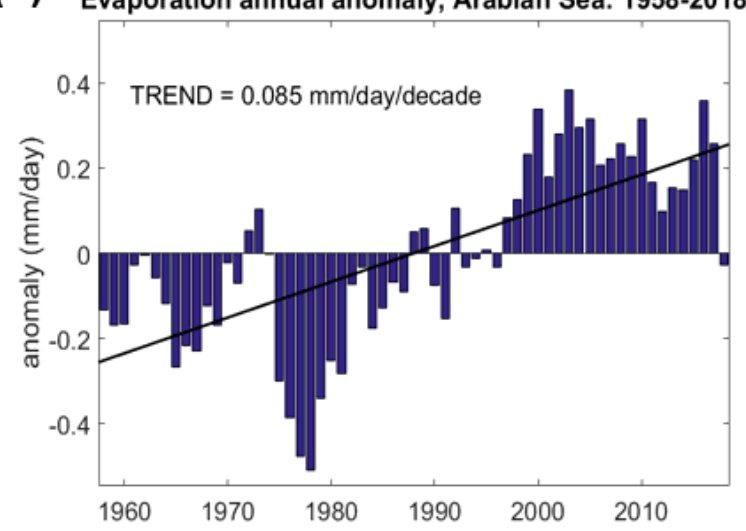

(b) Evaporation annual anomaly, Bay of Bengal: 1958-2018

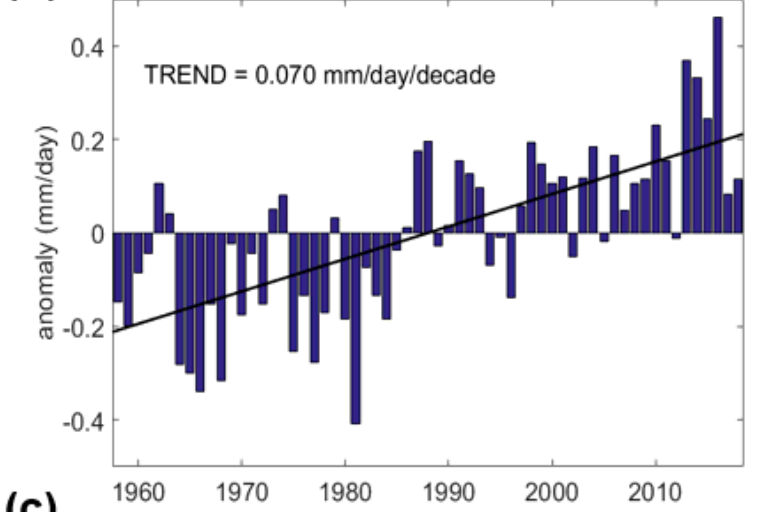

(c)

Evaporation annual anomaly, South China Sea: 1958-2018

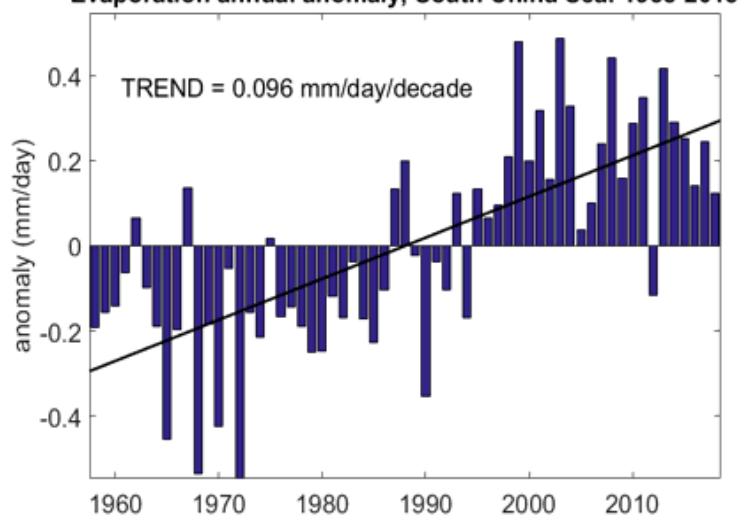

Figure 9

Area-averaged evaporation (OAFlux) annual anomalies over 1958-2018 for (a) Arabian Sea; (b) Bay of Bengal; (c) South China Sea. Linear trends (significant at the $99 \%$ confidence interval) are also depicted. 
(a)

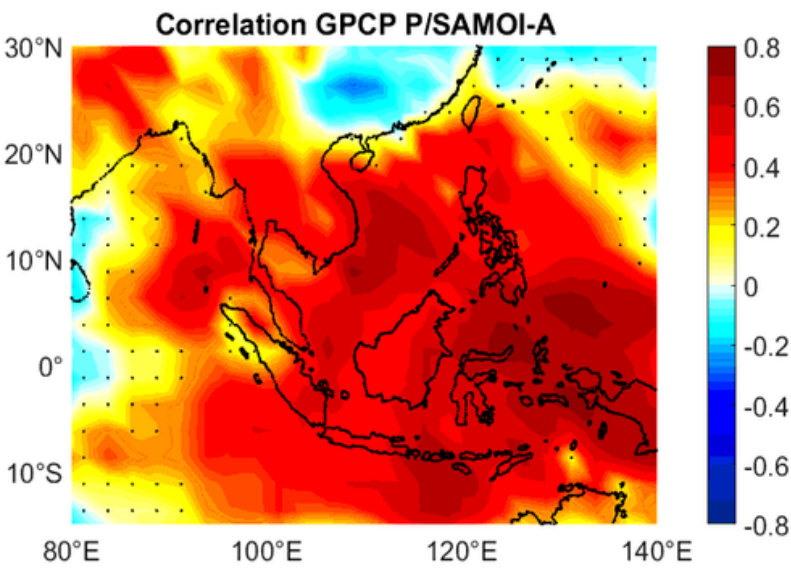

(c)

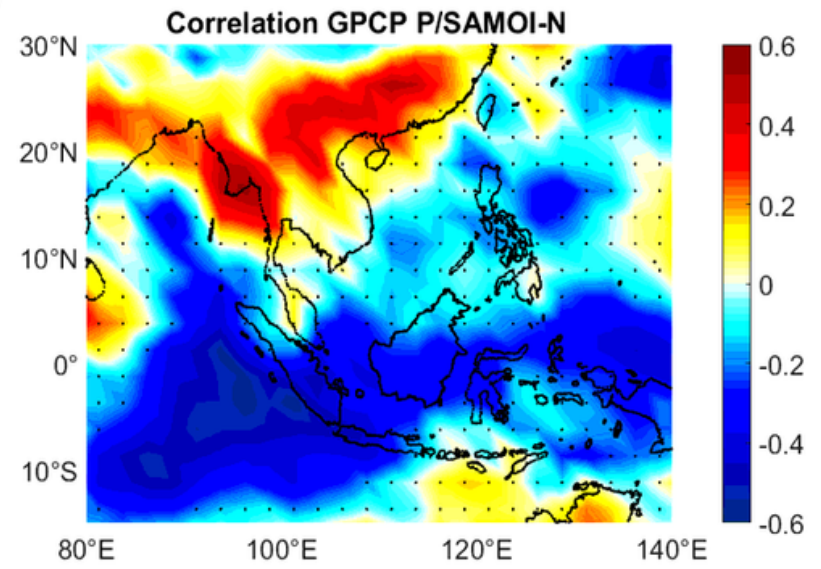

(b)

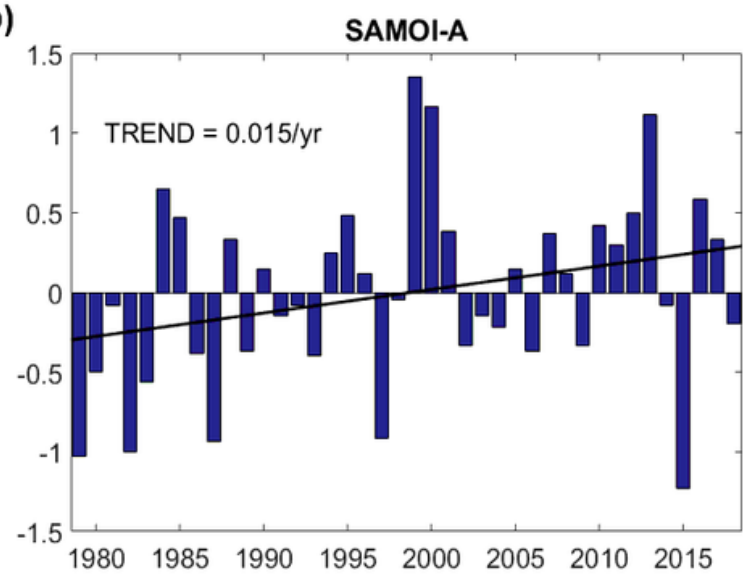

(d)

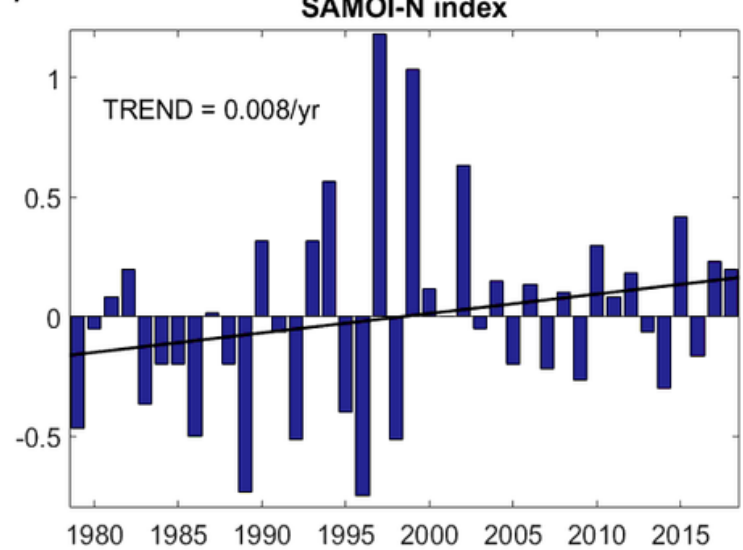

Figure 10

Correlation spatial patterns between annual mean precipitation (GPCP) and SAMOI-A and SAMOI-N index detrended timeseries (a, c). Regions where the correlation is not significant at the $95 \%$ confidence interval are stippled. SAMOI-A and SAMOI-N index annual timeseries over 1979-2018 (b, d). Linear trends (significant at the 90\% confidence interval) are also depicted. 
(a)



(b)
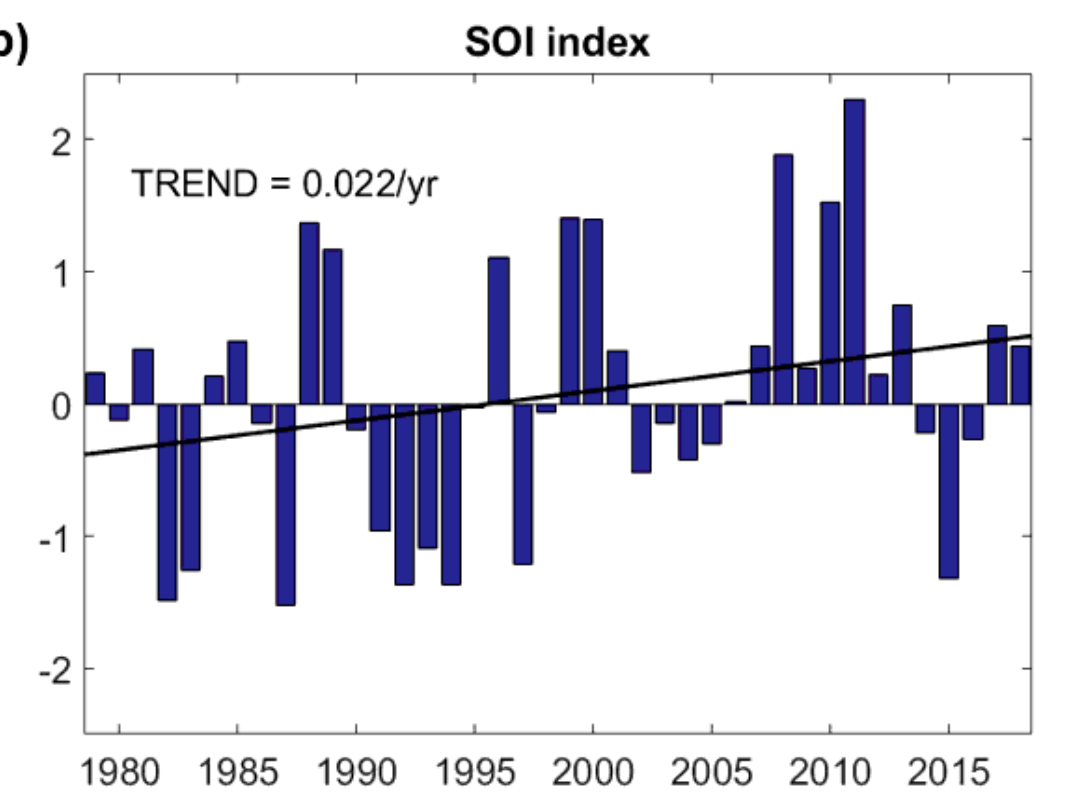

Figure 11

Correlation spatial pattern between annual mean precipitation (GPCP) and SOI (a). Regions where the correlation is not significant at the $95 \%$ confidence interval are stippled. SOI annual timeseries over 1979-2018 (b). The linear trend (significant at the $90 \%$ confidence interval) is also depicted. 
(a)

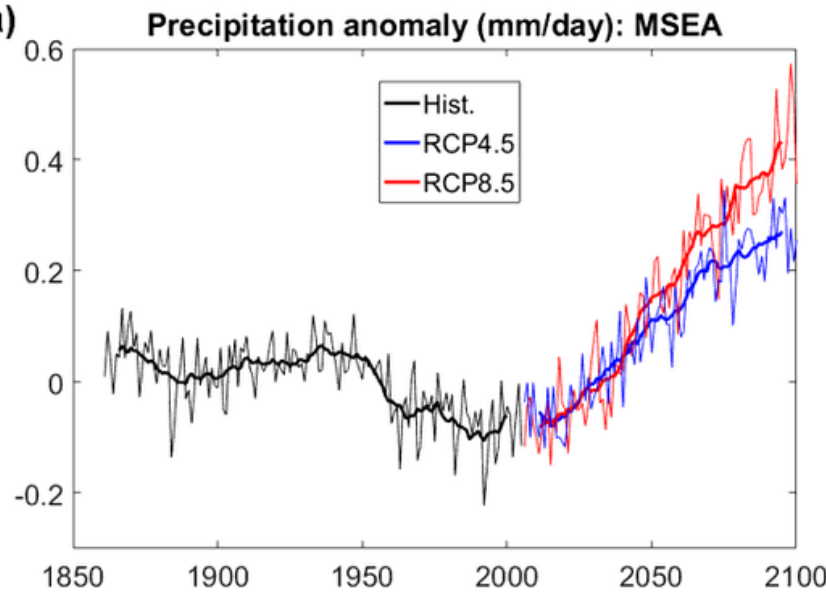

(c)

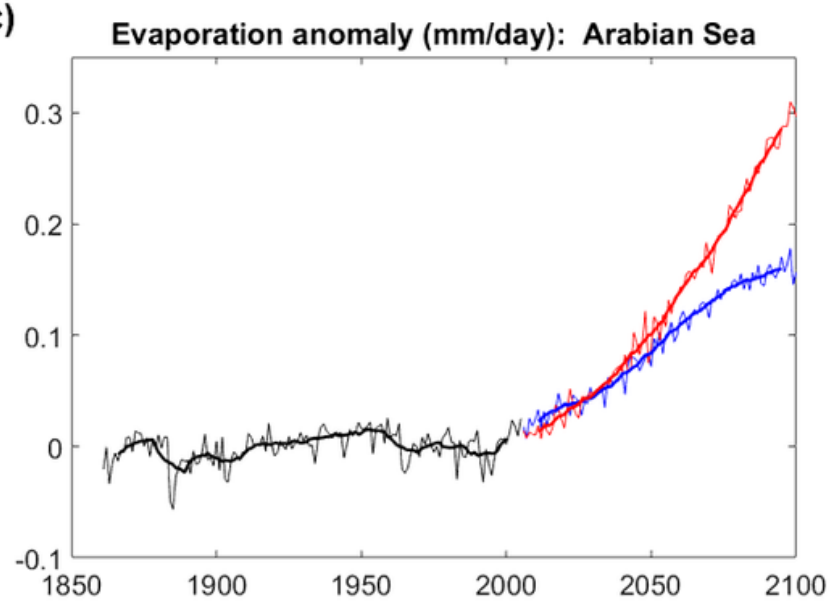

(b)



(d)

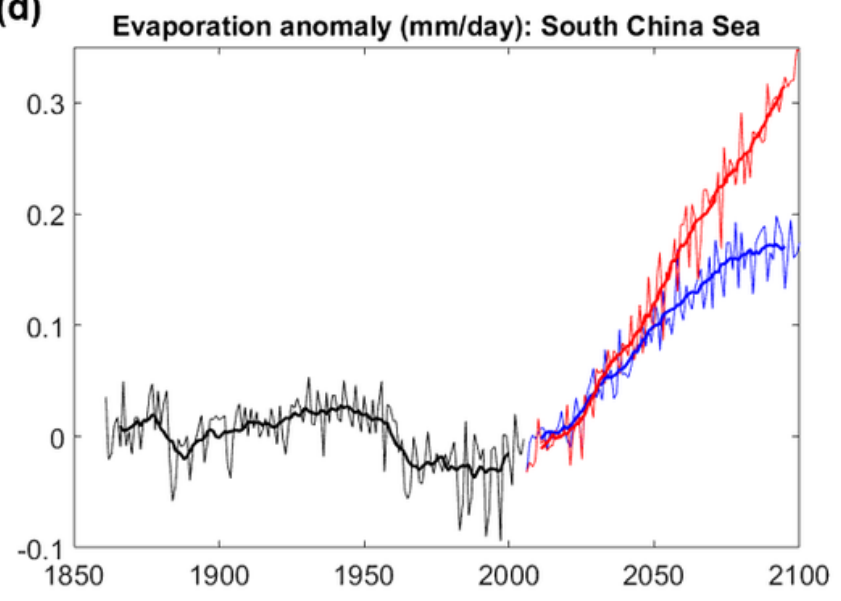

Figure 12

Annual timeseries of multi-model mean anomalies of land precipitation averaged over MSEA (a), and evaporation over the Arabian Sea (b), Bay of Bengal (c), and South China Sea (d) over 1860-2100 for historical (black), RCP4.5 (blue), and RCP8.5 (red) simulations. Thick solid lines depict 11-year running means. 